\title{
Growth, condition and metal concentration in juveniles of two Diplodus species in ports
}

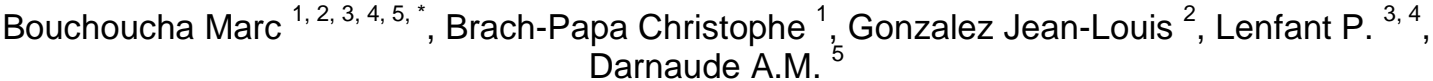

${ }^{1}$ Lab. Environnement Ressources Provence Azur Corse, Centre Ifremer de Méditerranée ZP de Brégaillon, CS 20330, 83507 La Seyne-sur-Mer, France

${ }^{2}$ Lab. Biogéochimie des Contaminants Métalliques, Centre Ifremer de Méditerranée ZP de Brégaillon, CS 20330, 83507 La Seyne-sur-Mer, France

${ }^{3}$ Univ. Perpignan Via Domitia, Centre de Formation et de Recherche sur les Environnements

Méditerranéens, UMR 5110, 58 Avenue Paul Alduy, F-66860 Perpignan, France

${ }^{4}$ CNRS, Centre de Formation et de Recherche sur les Environnements Méditerranéens, UMR 5110, 58

Avenue Paul Alduy, F-66860 Perpignan, France

${ }^{5}$ UMR MARBEC 9190 CNRS-UM-IRD-Ifremer, CC093, Université de Montpellier, Place Eugène

Bataillon, 34095 Montpellier, France

* Corresponding author : Marc Bouchoucha, email address : marc.bouchoucha@ifremer.fr

\begin{abstract}
:
High abundances of juvenile fish in certain ports suggest they might provide alternative nursery habitats for several species. To further investigate this possibility, post-settlement growth, metal uptake and body condition were estimated in 127 juveniles of two seabream species, collected in 2014-15, inside and outside the highly polluted ports of the Bay of Toulon. This showed that differences in local pollution levels (here in $\mathrm{Hg}, \mathrm{Cu}, \mathrm{Pb}$ and $\mathrm{Zn}$ ) are not consistently mirrored within fish flesh. Muscle metal concentrations, below sanitary thresholds for both species, were higher in ports for $\mathrm{Cu}, \mathrm{Pb}$ and $\mathrm{V}$ only. Otherwise, fish muscle composition principally differed by species or by year. Juvenile growth and condition were equivalent at all sites. Higher prey abundance in certain ports might therefore compensate the deleterious effects of pollution, resulting in similar sizes and body conditions for departing juvenile fish than in nearby natural habitats.
\end{abstract}

\section{Highlights}

- Growth, condition and contamination were assessed in Diplodus juveniles from ports. Muscle concentrations for trace elements were generally higher inside ports. Juvenile growth and condition were equivalents inside and outside ports. High primary production could compensate pollution deleterious effects in ports.

Keywords : Coastal areas, Nursery habitats, Fish, Contamination, Otoliths 
Introduction:

Understanding the life cycle of marine fishes is vital for their sustainable exploitation. The juveniles of many coastal species occupy various shallow habitats during their life stages. These habitats include estuaries (e.g. Beck et al., 2001; Vasconcelos et al., 2008; Vinagre et al., 2010), coastal lagoons (e.g. Abecasis et al., 2009; Franco et al., 2006), coral reefs (e.g. Carassou et al., 2009; Doherty, 1981), mangroves (e.g. Nagelkerken and Faunce, 2008), seagrass beds (e.g. Cheminee et al., 2013; Francour, 1999; Jones et al., 2013) and shallow coastal areas (e.g. Cheminee et al., 2011; Harmelin-Vivien et al., 1995; MacPherson, 1998). Since mortality rates in fish are maximal during the early phases of their life cycles, identification of their nursery habitats is particularly important for stock conservation (Jennings and Blanchard, 2004; Macpherson et al., 1997). In theory, fish nursery habitats must fulfill four conditions: they must support high abundances of juveniles, sustain faster somatic growth rates, allow higher survival and their populations must contribute more to the final adult stock (Beck et al., 2001). Therefore defining fish nursery habitats not only requires the identification of habitats with high juvenile densities but also those which enhance survival, growth rates and contribution to adult stocks. During the last few years, several studies suggested that coastal man-made infrastructures, particularly those found inside ports, might provide alternative nursery habitats for several rocky fish species (Bouchoucha et al., 2016; Clynick, 2006; Dufour et al., 2009; Pastor et al., 2013). However, this conclusion was solely based on the high abundances of juvenile fish observed in ports. To our knowledge, the impact of juvenile fish settlement in ports on their subsequent growth and physiological condition remains to be investigated.

Ports are among the most common man-made infrastructures found on the shoreline. Because they are semi-closed, calm and protected areas, they might provide favorable conditions for juvenile growth and survival (Harmelin-Vivien et al., 1995). However, they are generally integrated within cities or towns, and their influence on the environment is unavoidable (Darbra et al., 2005). Indeed, the very existence of a port already implies a certain loss of natural habitat. Furthermore, the industrial and yachting activities associated with ports result in chronic biological and chemical pollution of both the sediment and the water column inside and in the vicinity of port areas (Darbra et al., 2004). Chemical contaminants are well known to adversely affect fish physiology, growth and health, especially at 
young stages (e.g. Able et al., 1999; Amara et al., 2007; Kerambrun et al., 2013; Kerambrun et al., 2012). A commonly observed sub-lethal response of fish chronically exposed to contaminants is the modification of their energy allocation: it is used preferentially to resist chemical stress rather than for maintenance and growth (Rowe, 2003). This decreases global individual fitness as fish juveniles with slower growth and limited energy storage have lower survival rates and contribute less to the adult stock (Sogard, 1997). Juvenile fish exposure to chemical contaminants in ports is therefore expected to result in slower growth and poorer condition. Consequently, it is questionable that ports effectively correspond to the definition of fish nursery areas. Yet, many coastal habitats under high anthropogenic influence, like most estuaries and coastal lagoons, have been shown to sustain important densities of juvenile fish with high growth rates (Beck et al., 2001; Franco et al., 2006; Gibson, 1994) and are, as such, listed as nursery habitats for many species. As recipients of industrial and domestic wastes, these systems are subjected to moderate to high pollution (Amara et al., 2007; Courrat et al., 2009; Vasconcelos et al., 2011), which does not seem to alter their nursery function.

In this context, we measured and compared the post-settlement growth rates and the final body conditions and muscle metal concentrations of the juveniles of two sparids of the same genus (Diplodus Raffinesque, 1810) captured after at least 4.5 months of residency in two contrasted port areas of the Bay of Toulon (North-West Mediterranean) and in nearby coastal habitats matching their nursery area criteria. Further comparison of this data with concomitant in situ records of the environmental and pollution conditions experienced at each site allowed better assessment the value of port habitats as fish nursery areas and improved understanding of the potential consequences of their construction in terms of coastal fish stock dynamics. 


\section{$\mathrm{M} \& \mathrm{M}$}

Ethics statement

Sampling for this work was carried out in strict accordance with French legislation. After collection, juvenile individuals were immediately euthanized in ice slurry. The sampling activity did not involve endangered or protected species.

\section{Model species}

Two coastal rocky fish species of the same genus were selected for this study: the white seabream $D$. sargus sargus (Linnaeus, 1758), hereafter $D$. sargus, and the two-banded seabream $D$. vulgaris (Geoffroy Saint-Hilaire, 1817). These two sparids are common in the Mediterranean and have high ecological and commercial value (Coll et al., 2004; Lloret et al., 2008; Morales-Nin et al., 2005). They are highly abundant in both natural and artificial rocky coastal areas (Tortonese, 1965) and their juvenile habitat use is fairly well known (Bouchoucha et al., 2016; Cheminee et al., 2011; GarcíaRubies and Macpherson, 1995; Harmelin-Vivien et al., 1995; Ventura et al., 2014; Vigliola et al., 1998): D. sargus settles in one pulse only, in June-July, and usually leaves its nursery grounds in September; conversely $D$. vulgaris settles in two pulses, one in November-December and one in January-February, and leaves its nursery grounds in June-July. Moreover, as migration is very limited in Diplodus juveniles (Macpherson et al 1997) and given the distance between our sampling sites (between 1.5 and $8 \mathrm{~km}$ ), the post-settlement growth, body condition and contamination levels of the juveniles of the two species should correctly reflect the quality of the sites in which they were collected. Given the complementarity of the periods of residency of the two species over the year, investigating their respective reactions to different habitat types should allow reaching more general conclusions regarding habitat suitability with regards juvenile fish growth, condition and contamination. 
Our study was carried out within the Bay of Toulon, located in the northwest French Mediterranean (Fig. 1) and surrounded by the city of Toulon (ca. 600000 inhabitants). The Bay of Toulon is divided into the "Large Bay" $\left(42.2 \mathrm{~km}^{2}\right)$ and the "Small Bay" $\left(9.8 \mathrm{~km}^{2}\right)$, separated by a breakwater $(1200 \mathrm{~m})$ built in the nineteenth century (Fig.1). The Small Bay harbors one of the largest industrial ports of France and six marinas. Almost all natural habitats have disappeared from this area. Its semi-enclosed morphology, micro-tidal conditions and intermittent freshwater inputs (Nicolau et al., 2012), lead to relatively long water residence times (Dufresne et al., 2014). Consequently, local historic (e.g. World War II) and present anthropogenic activities have resulted in strong multi-contamination of its sedimentary compartment (Dang et al., 2015; Pougnet et al., 2014; Tessier et al., 2011) and water column (Dang et al., 2015; Jean et al., 2012). Conversely, the Large Bay opens onto the Mediterranean and is little affected by human activities (Tessier et al., 2011). Its shoreline, about $13 \mathrm{~km}$ in length, is rocky and natural, except for two small marinas and three artificial beaches.

In this work, four contrasting sampling sites were selected: two as representative of the different types of ports present in the Bay of Toulon and two as representative of the other types of coastal habitats available for the juveniles of local rocky fishes. Previous observations had confirmed the regular presence of the juveniles of the two species at the four sites, where they had repeatedly been seen in abundance and at different sizes (personal observation). The first sampling site (STM) was positioned in the Saint-Mandrier marina, within the Small Bay (Fig. 1). This port, representative of the marinas found in the Bay of Toulon, harbors 800 boats and pleasure craft and its average depth varies between 2.5 and $4 \mathrm{~m}$. It is protected by two breakwaters that separate it from the rest of the bay. Sampling at this site was made inside the port, on the landward side of its eastern breakwater. The second site (TLN) was positioned further within the Small Bay (Fig. 1), in one of the most contaminated parts of the Bay of Toulon (Tessier et al., 2011; Wafo et al., 2016) located at about $500 \mathrm{~m}$ from the biggest naval port of the Mediterranean (the port of Toulon, which harbors around 30 warships and nuclear submarines) and less than $200 \mathrm{~m}$ from a large ferry terminal serving the Corsica island (ca. 1,000 rotations and 1.2 million passengers per year). As for STM, sampling was carried out on the landward 
side of a breakwater. The third sampling site (DLE) was positioned on the seaward side of the main breakwater that separates the Small Bay from the Large Bay (Fig. 1), in an area that is very little impacted by port pollution (Tessier et al., 2011; Wafo et al., 2016). In the Mediterranean, the seaward sides of peripheral breakwaters have been shown to be colonized by the juvenile of numerous fish species and are generally considered as favorable habitats for juvenile fish growth (Clynick, 2006; Dufour et al., 2009; Guidetti, 2004; Pastor et al., 2013; Pizzolon et al., 2008; Ruitton et al., 2000). Therefore, the DLE site was chosen as a representative of the non-polluted artificial nursery habitats available for rocky fishes within the Bay of Toulon. Physical habitat characteristics (substrate, depth, etc.) are equivalent in the STM, TLN and DLE sampling sites. The last sampling site (MAG) was positioned within the Large Bay (Fig. 1), in a natural cove (Anse Magaud) whose physical habitat characteristics match those identified as the most suitable for the benthic settlement of Diplodus species, i.e. shallow coastal habitats (between 0 and $2 \mathrm{~m}$ ) protected from prevailing winds and characterized by gentle slopes covered with sand, pebbles and boulders (Cheminee et al., 2011; Harmelin-Vivien et al., 1995). Therefore, this site was chosen as a representative of the natural rocky fish nursery habitats available in the Bay of Toulon.

Fish sampling for this study was to be carried out in 2014 and 2015, during the month preceding juveniles' departure dates for each species, i.e. after at least 4.5 months of residency in each habitat. Unfortunately, we failed to collect $D$. sargus juveniles in 2015. Therefore, $D$. sargus juveniles in this work were collected in late August- early September 2014 only, whereas D. vulgaris juveniles were collected both in 2014 and in 2015, in early July for both years. At each location, fish were sampled between 0 and $2.5 \mathrm{~m}$ depth using hand-nets. The juveniles of the two species were discriminated following the morphometric and size criteria of Vigliola and Harmelin-Vivien (2001).

\section{Environmental and chemical contamination data}

Metal bioavailability in the environment can be estimated by various methods. Among them, the use of Diffusive Gradient on Thin film devices (DGT) allows gathering integrative values of water concentrations in the most labile dissolved metal species (Davison and Zhang, 1994). DGTs 
concentrate the most highly labile dissolved cations, as defined operationally (hydrated ions, mineral complexes, and weak or rapidly dissociable organic complexes). Indeed, during their immersion period, DGT accumulate ionic forms and weakly dissociable complexes (hereafter named the DGTlabile fraction) on a Chelex 100 resin, proportionally to their water concentration over the entire exposure time. This DGT- labile fraction is considered more representative of the fraction potentially bioavailable than the total metal concentration (Odzak et al., 2002; Twiss and Moffett, 2002; Zhang and Davison, 2001).

For this study, three DGT were immersed at $1.5 \mathrm{~m}$ depth for 15 days each month, from January to July 2015 , in order to record local metal concentrations at each of the four sampling sites over 7 consecutive months. During this period, water temperature and salinity were also recorded at each site using a CTD probe (YSI Pro30), and monthly samples of surface water were taken to investigate local variations in primary productivity (Chlorophyll a concentrations). Three DGT devices were selected as control and not immersed in the seawater.

To quantify the DGT- labile fraction bioavailable at each site for each month, the Chelex 100 resin of the DGT probes was peeled off in the laboratory and trace elements were extracted in $1.8 \mathrm{ml}$ of $1 \mathrm{M}$ ultrapure nitric acid $(24-48 \mathrm{~h})$. Concentrations in the acid extracts were analyzed for seven trace elements $(\mathrm{Cr}, \mathrm{Pb}, \mathrm{Mn}, \mathrm{Zn}, \mathrm{Cu}, \mathrm{Fe}$ and $\mathrm{Al})$ using ICP-MS to determine the mass of metal (M) accumulated by the DGT. Then, for each trace element, the average labile concentrations in water $\left(C_{\text {DGT }}\right)$ were calculated using the following equation (Zhang et al., 1995) :

$\mathrm{C}_{\mathrm{DGT}}=(\mathrm{M} \cdot \Delta \mathrm{g}) /\left(\mathrm{D}_{\mathrm{m}} \cdot \mathrm{t} \cdot \mathrm{A}\right)$

Where $\mathrm{M}$ is the mass of the trace element accumulated in the resin, $\Delta \mathrm{g}$ is the diffusive layer thickness, Dm is the diffusion coefficient of the trace element provided by DGT Research (www.dgtresearch.com), $\mathrm{t}$ is the immersion of the DGT probe, and A is the exposure area. 
Chlorophyll a (Chl a) concentrations for each site and month were estimated by filtering $1 \mathrm{~L}$ of water through Whatman GF/F filters (pore diameter $=0.7 \mu \mathrm{m}$ ) under vacuum conditions. The resulting filters were placed in glass tubes and stored separately at $-20{ }^{\circ} \mathrm{C}$ until they could be analysed. For this, each filter was ground separately in acetone $90 \%$ and the resulting solution was incubated for $24 \mathrm{~h}$ in the dark at $4{ }^{\circ} \mathrm{C}$ before measurement of pigment concentrations by spectrofluorimetry (Neveux and Lantoine, 1993).

\section{Fish post-settlement growth and final condition}

Upon collection, the juveniles of the two species were transported on ice to the laboratory, measured (total length TL, in $\mathrm{mm}$ ), weighed (total mass $\mathrm{M}$, in $\mathrm{g}$ ) and stored at $-20^{\circ} \mathrm{C}$. Their body condition was estimated based on the Fulton's index K (Ricker, 1975):

$\mathrm{K}=10^{5} \mathrm{M} / \mathrm{TL}^{3}$

where $\mathrm{M}$ is the total wet mass in $\mathrm{g}$ and TL the total length in $\mathrm{mm}$.

This morphometric index assumes that heavier fish for a given length are in better condition (Ricker, 1975).

Fish post-settlement growth rates for this study were derived from otolith (ear stones) reading. Otoliths are paired calcified structures located in the inner ear of teleost fishes. Their use has become standard in marine ecology and fishery research. They provide a great deal of information on the life histories of fishes, particularly at the juvenile stage (Campana, 1999). Many studies reported the daily formation of otolith increments in larvae and juveniles of various species. As a result, counts of increments in otoliths have enabled the determination of juvenile fish ages on a daily basis (Campana and Jones, 1992; Pannella, 1971). Moreover, at the individual level, otolith growth rate is directly related to somatic growth rate (Campana and Thorrold, 2001; Wilson et al., 2009). Therefore, the length of the otolith radius can be used as a proxy of fish somatic growth.

For each fish, the left sagital otolith was extracted, washed and prepared for daily ring counts. Otoliths were embedded individually in Crystalbond resin and ground in the transversal plane using 1200, 2400 and 4000 grit silicate paper until the core (primordium) was exposed. Then, the otolith sections were 
flipped over and polished down to reach an average thickness of $20 \mu \mathrm{m}$. As daily otolith increment deposition has been validated for both $D$. sargus and D. vulgaris (Vigliola, 1997), daily rings count can be used for age estimation in their juveniles. Moreover, the sagital otoliths of both $D$. sargus and D. Vulgaris exhibit a benthic settlement mark, described as a series of shaded daily increments (Di Franco et al., 2011; Vigliola et al., 2000). Therefore, within each otolith, it is possible to discriminate between the larval pelagic and the juvenile benthic periods of growth. Post-settlement increments were counted from the settlement mark to the edge of the otolith. Corresponding distances (in $\mu \mathrm{m}$ ) were also measured along the maximum otolith growth axis. Finally, the post-settlement daily absolute growth rate (AGR, Panfili, 2002) was calculated for each fish using the equation:

$\mathrm{AGR}=\mathrm{D} / \mathrm{T}$

where $\mathrm{D}$ is the distance (in $\mu \mathrm{m}$ ) and $\mathrm{T}$ the number of daily increments (in day) between the settlement mark and the edge of the otolith.

Trace element concentrations in fish muscle tissue

For each sampling site, ca. 5 individuals of each species and year were selected randomly for analysis of their body concentrations in 12 trace elements ( $\mathrm{Al}, \mathrm{As}, \mathrm{Cr}, \mathrm{Cu}, \mathrm{Fe}, \mathrm{Hg}, \mathrm{Mn}, \mathrm{Pb}, \mathrm{Se}, \mathrm{Ti}, \mathrm{V}$ and $\mathrm{Zn}$ ). All the materials used for muscle dissection and sample preparation were previously decontaminated by $4 \%$ ultrapure nitric acid baths, triple rinsed with ultrapure water $(18.2 \mathrm{M} \Omega)$ and dried under a class 100 clean bench.

For each individual a dorsal muscle sample was dissected, freeze-dried and ground into powder. Total mercury (hereafter $\mathrm{Hg}$ ) analyses were carried out directly on 10-100 mg sub-samples of fish muscle powder (untreated) using an Advanced Mercury Analyzer (ALTEC AMA 254). For Hg determination, the metal was evaporated by progressive heating up to $800^{\circ} \mathrm{C}$, then kept in an oxygen atmosphere for three minutes, and amalgamated on a gold net. Afterwards, the net was heated to release the collected $\mathrm{Hg}$ which was finally measured by atomic absorption spectrophotometry. $\mathrm{Hg}$ analyses were run according to a thorough quality control program including periodic analysis of a certified reference 
material DORM-4 (fish protein, CNRC-NRC) chosen in accordance with the assumed Hg content of the sample.

For the other trace elements, aliquots (100-200 mg) of muscle powder were first placed in a microwave oven (MARS-5, CEM Corporation) to be digested with $8 \mathrm{ml}$ of ultrapure nitric acid under controlled temperature and pressure conditions. After cooling, the digests were diluted to $50 \mathrm{ml}$ with milli-Q water. The concentrations of $\mathrm{Al}, \mathrm{As}, \mathrm{Cr}, \mathrm{Cu}, \mathrm{Fe}, \mathrm{Mn}, \mathrm{Pb}, \mathrm{Se}, \mathrm{Ti}, \mathrm{V}$ and $\mathrm{Zn}$ were determined using an ICP-Q-MS (iCAP Qc, ThermoFisher Scientific) equipped with a Peltier-cooling system, a quartz cyclonic spray chamber, a $200 \mu 1 . \mathrm{mn}^{-1}$ PFA nebulizer and Nickel standard cones with insert. Elemental concentrations (in mg. $\mathrm{kg}^{-1}$ of dry mass, $\mathrm{dm}$ ) were determined using external calibration (4 to 6 points) in diluted $\mathrm{HNO}_{3}(3 \%)$. A known amount of internal standard solution $\left({ }^{45} \mathrm{Sc},{ }^{89} \mathrm{Y},{ }^{115} \mathrm{In}\right.$ and

${ }^{209} \mathrm{Bi}$ ) was added to all the solutions to monitor for instrumental drift and matrix effects. Depending on the element, measurements were performed using standard (STD) or Kinetic Energy Dispersion (KED) modes. ICP-MS analyses were run according to a thorough quality control program including repeated analysis of certified reference material DORM-4 (fish protein, CNRC-NRC) and IAEA-407 (fish tissue, IAEA). Detection limits (LODs) were estimated at 0.50, 0.05, 0.05, 0.25, 0.25, 0.05, 0.05, 0.25, 0.10, 0.10 and 1.00 mg.kg ${ }^{-1} \mathrm{dm}$ for $\mathrm{Al}, \mathrm{As}, \mathrm{Cr}, \mathrm{Cu}, \mathrm{Fe}, \mathrm{Mn}, \mathrm{Pb}, \mathrm{Se}, \mathrm{Ti}, \mathrm{V}$ and $\mathrm{Zn}$, respectively. Element concentrations below LODs were set to zero.

Statistical analyses

All statistical analyses were performed using the PRIMER 6 software with the PERMANOVA add-on (Clarke and Warwick, 2001). The significance level for the tests was consistently set at $\alpha=0.05$.

Spatial variations in age, total length, juvenile growth rate and final fish body condition and trace element concentrations were analyzed for the two species, separately or grouped, according to the sampling site. Interspecific and inter-annual variations were tested using data from $D$. sargus and $D$. vulgaris in 2014 and from D. vulgaris in 2014 and 2015, respectively. Differences in ambient 
environmental conditions (temperature, salinity and $\mathrm{Chl}$ a levels) and in water elemental composition among sampling sites (TLN, STM, DLE or MAG) were tested separately. To do this, PERMANOVAs were performed. They allow handling complex, unbalanced and multiple-factor designs, and considering interactions between factors. In addition, they do not assume normal error distributions (Anderson, 2001). Euclidean distance similarity matrixes were generated and the factors Species (with two levels: D. sargus and D. vulgaris), Year (with two levels: 2014 and 2015) and Site (with four levels: TLN, STM, DLE and NAT) were treated as fixed. Data were $\log (\mathrm{X}+1)$ transformed prior to statistical analyses. In each case, p-values were calculated by 9999 random permutations of residuals (Anderson, 2001).

\section{Results}

Differences in environmental conditions among sites

Temperature and salinity conditions were similar $(\mathrm{p}>0.695)$ at all sampling sites (Table 1$)$, the average values over the seven months surveyed ranging from $17.1 \pm 3.9^{\circ} \mathrm{C}$ (at DLE) to $17.7 \pm 4.9^{\circ} \mathrm{C}$ (at STM) for temperature, and from $37.7 \pm 1.0$ (at TLN) to $38.0 \pm 0.8$ (at DLE) for salinity. Conversely, primary production levels differed significantly ( $\mathrm{p}>0.02)$ among sites (Table 1), with 1.5-1.7 times higher average water concentrations in $\mathrm{Chl}$ a in the two ports $\left(0.48 \pm 0.33 \mu \mathrm{g} . \mathrm{l}^{-1}\right.$ at TLN and $0.37 \pm 0.23 \mu \mathrm{g} .1^{-1}$ at STM $)$ than at the $\operatorname{DLE}\left(0.27 \pm 0.17 \mu \mathrm{g} .1^{-1}\right)$ and MAG $\left(0.27 \pm 0.20 \mu \mathrm{g} .1^{-1}\right)$ sites. With regards contamination, only the water concentrations in $\mathrm{Cu}, \mathrm{Pb}$ and $\mathrm{Zn}$ differed significantly $(\mathrm{p}<$ 0.026) according to the sampling site (Fig. 2), with consistently lower water concentrations at MAG, and higher ones in the ports. However, water concentrations in $\mathrm{Cu}$ were maximal at STM (2 $971 \pm 997$ ng. $1^{-1}$ ), while for Pb, the highest values were recorded at TLN (328 \pm 107 ng.l-1). For Zn, water concentrations were similar at the two port sites, with average values of $3.3 \pm 0.78 \mu \mathrm{g} . \mathrm{l}^{-1}$ at STM and $3.1 \pm 1.7 \mu \mathrm{g} .1^{-1}$ at TLN. For the other trace elements investigated (Al, Cr, Fe and Mn), spatial differences in water concentrations were not significant $(p>0.078)$ due to important variations at certain sites. However, the highest local water concentrations in $\mathrm{Fe}\left(0.69 \pm 1.0 \mu \mathrm{g} . \mathrm{l}^{-1}\right)$ and in $\mathrm{Mn}(1.5 \pm$ 

port, at STM (averages of $0.61 \pm 0.18 \mu \mathrm{g} \cdot \mathrm{l}^{-1}$ and $49 \pm 15 \mathrm{ng} . \mathrm{l}^{-1}$, respectively).

Body condition and juvenile growth rate

For the 127 individuals included in this work, post-settlement growth rate (AGR) and body condition

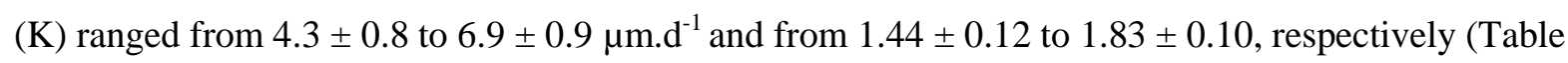
2). For both parameters, significant variations were found both by species $(\mathrm{p}<0.001)$ and by year $(\mathrm{p}$ $<0.001)$, with higher $(\mathrm{p}<0.001)$ growth rates and body conditions for D. sargus in 2014 (AGR = 6.6 $\pm 0.8 \mu \mathrm{m} . \mathrm{d}^{-1}$ and $\left.\mathrm{K}=1.80 \pm 0.10\right)$ and D. vulgaris in $2015\left(\mathrm{AGR}=5.4 \pm 0.6 \mu \mathrm{m} \cdot \mathrm{d}^{-1}\right.$ and $\mathrm{K}=1.62 \pm$ $0.12)$ than for $D$. vulgaris in $2014\left(\mathrm{AGR}=4.6 \pm 0.8 \mu \mathrm{m} \cdot \mathrm{d}^{-1}\right.$ and $\left.\mathrm{K}=1.49 \pm 0.14\right)$. Variations according to the sampling site were less marked (Table 2, Fig. 3). They only concerned D. sargus in 2014, with significantly $(\mathrm{p}<0.042)$ lower growth rates in TLN $\left(6.1 \pm 0.7 \mu \mathrm{m} \cdot \mathrm{d}^{-1}\right)$ than in DLE $\left(6.8 \pm 0.9 \mu \mathrm{m} \cdot \mathrm{d}^{-1}\right)$ and in MAG $\left(6.9 \pm 0.9 \mu \mathrm{m} . \mathrm{d}^{-1}\right)$, while STM showed intermediate values $\left(6.5 \pm 0.6 \mu \mathrm{m} . \mathrm{d}^{-1}\right)$. Body condition did not differ significantly among sampling sites for this species and year $(p=0.184)$ and, for D. vulgaris, both parameters were similar at all sites, irrespective of the year considered ( $\mathrm{p}>$ 0.087).

Trace element concentrations in fish muscle

For the 12 element investigated, muscle concentrations were over detection limits in all the fish analyzed (Table 3). Contamination levels in $\mathrm{Al}, \mathrm{As}, \mathrm{Cr}, \mathrm{Hg}, \mathrm{Mn}, \mathrm{Pb}$ and $\mathrm{V}$ differed significantly between the two species $(\mathrm{p} \leq 0.025)$, with higher muscle concentrations in $D$. sargus for As and $\mathrm{Hg}(\mathrm{p}$ $\leq 0.020)$ and in D. vulgaris for $\mathrm{Al}, \mathrm{Cr}, \mathrm{Mn}, \mathrm{Pb}$ and $\mathrm{V}(\mathrm{p} \leq 0.025)$. However, elemental concentrations in the flesh of the fish also apparently depended on the year: for D. vulgaris, muscle concentrations in As and $\mathrm{Cr}$ were higher in 2014 ( $\mathrm{p} \leq 0.009)$, whereas those in $\mathrm{Cu}, \mathrm{Mn}, \mathrm{Ti}$ and $\mathrm{V}$ were higher in 2015 (p $\leq 0.003$ ) (Table 3, Fig. 4, Fig. S1). 
When considering both species grouped, muscle concentrations only varied significantly $(p \leq 0.037)$ according to the sampling site for $\mathrm{Cu}, \mathrm{Mn}, \mathrm{Pb}$ and $\mathrm{V}$ (Table 3, Fig. 4). The highest muscle concentrations were observed in STM for $\mathrm{Cu}\left(3.8 \pm 1.9 \mathrm{mg} \cdot \mathrm{km}^{-1} \mathrm{dm}\right)$ and $\mathrm{V}\left(1.1 \pm 1.0 \mathrm{mg} \cdot \mathrm{km}^{-1} \mathrm{dm}\right)$, in DLE for Mn $\left(1.8 \pm 1.2 \mathrm{mg} \cdot \mathrm{km}^{-1} \mathrm{dm}\right)$, and indifferently $(\mathrm{p}=0.268)$ in TLN $\left(0.21 \pm 0.09 \mathrm{mg} \cdot \mathrm{km}^{-1} \mathrm{dm}\right)$ or in DLE $\left(0.17 \pm 0.11 \mathrm{mg} \cdot \mathrm{km}^{-1} \mathrm{dm}\right)$ for $\mathrm{Pb}$ (Table 3, Fig. 4). Differences in element concentrations among sites depended both on the species and the year $(\mathrm{p}<0.001)$. Spatial variations for $D$. sargus in 2014 were significant for $\mathrm{Cu}, \mathrm{Fe}, \mathrm{Mn}, \mathrm{Pb}, \mathrm{Zn}$ and $\mathrm{V}(\mathrm{p} \leq 0.041)$, but for $D$. vulgaris they concerned only Al, $\mathrm{Hg}$ and $\mathrm{V}$ in 2014 (p $\leq 0.031$ ) and Al, Cu, Hg, Mn, Se, Ti and V in 2015 (p $\leq 0.013$ ) (Fig. 4, Fig. S1). For all these elements, when spatial variations existed, the highest concentrations were systematically observed in a port site, TLN or STM, with exception of Mn, for which the highest concentrations were found in DLE (Table 3, Fig. 4, Fig. S1).

\section{Discussion}

Very few studies so far have simultaneously assessed the condition, growth history and contamination levels of fish juveniles captured in ports. To our knowledge, this is the first time that this has been investigated this thoroughly. Unfortunately, due to technical and logistic constraints, solely seven trace elements out of 12 were measured in the water column in this work, and environmental parameters could only be recorded during the seven months of $D$. vulgaris presence in the four juvenile habitats. However, this time period also covered the first month of juvenile residency for D. sargus. Therefore, matching the environmental data gathered in this work in both the port areas and at nearby coastal sites with the physiological and contamination response of the two fish species on these contrasted juvenile habitats allowed improving our understanding about port use by rocky fishes and their value as nursery sites. Notwithstanding the limitations inherent to small samples (in terms of number of species, individuals and sites studied) that might weaken certain generalizations, our results demonstrate that higher levels of environmental pollution in ports do not necessarily result in higher muscle contamination, reduced growth or poorer condition for the fish juveniles that inhabit them. 
Environmental contamination and fish contamination

Contamination levels in fish are generally estimated from liver samples because, for all metals but $\mathrm{Hg}$, concentrations are usually the highest in this tissue (Henry et al., 2004). In the present study, muscle tissue was used instead. Indeed, the small size of the fish sampled did not allow collection of enough liver material for metal concentration analyses. Moreover, in exploited species like $D$. sargus and $D$. vulgaris, analysis of muscle contamination levels is of great interest as this tissue is usually that which humans consume. Besides, metal contents in fish liver and muscle tissues are generally positively correlated and when inter-site differences are found for fish liver they are generally mirrored in the muscle tissue (Henry et al., 2004).

Although numerous studies have measured metal concentrations in marine fish (e.g. Chouvelon et al., 2017; Cresson et al., 2014; Nakhle et al., 2007), this information is still very limited for Diplodus species. Our results therefore provide valuable information about muscle contamination in these two species, especially for $\mathrm{Al}$ and $\mathrm{Ti}$, for which very few data exist in the literature. To our knowledge, only one study so far has measured metal concentrations in the muscle of Diplodus juveniles in the wild, in D. vulgaris from six natural estuarine nursery sites spread along the Portuguese coast, and considered as slightly to moderately polluted (Vasconcelos et al., 2011). Muscle contamination levels for $\mathrm{Cu}$ and $\mathrm{Zn}$ in this work (of $2.1 \mathrm{mg} \cdot \mathrm{kg}^{-1} \mathrm{dm}$ and $28 \mathrm{mg} \cdot \mathrm{kg}^{-1} \mathrm{dm}$ on average, respectively) were close to those found for D. vulgaris in our study (Table 3), with the exception of the Cu concentrations observed in STM (2.0-8.9 mg. $\left.\mathrm{kg}^{-1} \mathrm{dm}\right)$. Unfortunately, the detection limit for the study of Vasconcelos et al. (2011) was much higher $\left(0.7 \mathrm{mg} \cdot \mathrm{kg}^{-1} \mathrm{dm}\right)$ than that allowed by our analytical method $(<0.5$ mg.kg ${ }^{-1} \mathrm{dm}$ ), which prevented successful measurement of muscle concentrations in $\mathrm{Al}, \mathrm{As}, \mathrm{Cr}, \mathrm{Fe}, \mathrm{Mn}$, $\mathrm{Pb}, \mathrm{Se}, \mathrm{Ti}$ or $\mathrm{V}$ by these authors. For these elements in D. vulgaris and for all elements in D. sargus there is no published data available to compare our results with. Since trace element uptake apparently varies by species, further work is required before we can resituate our results in a broader context and fully evaluate the significance of the metal concentrations measured here for the biology and the ecology of $D$. sargus and $D$. vulgaris. 
In our study, juvenile fish were collected after several months of life in one of the major ports of the French Mediterranean coast, in an area amongst the most contaminated in the world. However, their muscle metal concentrations were well below sanitary thresholds: for $\mathrm{Pb}$ and $\mathrm{Hg}$ for example, even the average concentrations measured at TLN were 5 and 7.5 times lower, respectively, than official threshold limits (Commission Regulation EC N. 1881/2006). Therefore, consuming the flesh of these fish would not represent a risk for human health. Besides, their metal concentrations are likely to further decrease until they reach commercial sizes, through biodilution by somatic growth in natural habitats that are probably little polluted (Cossa et al., 2012; Cresson et al., 2015; Harmelin-Vivien et al., 2009).

Trace metals uptake in fish is influenced by multiple factors, but depends primarily on their concentration in the environment (Das, 2000). Except for Mn, when spatial variations existed in our study area, metal concentrations in fish juveniles were systematically higher inside ports than outside them. This is not surprising because ports are usually major focal points of industrial (shipping, loading and unloading, accidental spills) and urban (wastewater emissions) activities, and are recognized as one of the main locations where metals accumulate, in particular in sediments (e.g. Adamo et al., 2005; Schintu and Degetto, 1999; Schintu et al., 2016; Tessier et al., 2011). Analysis of the sediments from the Bay of Toulon revealed extreme concentrations in $\mathrm{Hg}, \mathrm{Cu}, \mathrm{Pb}$ and $\mathrm{Zn}$ in the vicinity of the port of Toulon, where the TLN site was positioned, with $\mathrm{Hg}$ concentrations amongst the highest ever measured in a marine system (Dang et al., 2015; Pougnet et al., 2014; Tessier et al., 2011; Wafo et al., 2016). On the contrary, in the Large Bay where the DLE and MAG sites are located, sediments are much less contaminated by metal compounds, as their concentrations in this compartment gradually decrease with the distance from the ports (all located in the Small Bay), to reach the natural concentrations found in the Mediterranean (Tessier et al., 2011). Our measurements in the water column (for $\mathrm{Cu}, \mathrm{Pb}$ and $\mathrm{Zn}$ ) are consistent with these observations. Apparently, spatial differences in fish contamination in the Bay of Toulon therefore reflect differences in environmental contamination levels between the Small and the Large Bay. However, when considering each trace 
element individually, spatial variations in environmental contamination did not always match those observed in the flesh of the Diplodus juveniles.

The metals analyzed here differ fundamentally in their metabolic role and their regulations by aquatic organisms. Elements like $\mathrm{Cu}, \mathrm{Fe}, \mathrm{Mn}, \mathrm{Se}$ and $\mathrm{Zn}$ are essential in fish metabolism and cannot be synthesized (Amiard et al., 1987). They are generally efficiently regulated by marine animals, and present a narrow range of variation in their tissues, except when ambient concentrations in seawater or food reach very high concentrations (Amiard et al., 1987; Chapman, 1996; Vallee and Auld, 1990). This can explain why spatial variations in muscle Zn concentrations were low irrespective of the species or the year although concentrations in the water for this element were $\sim 3$ times higher at the two port sites (Fig. 2). By contrast, fish muscle concentrations were found to be 1.6 times higher for $\mathrm{Cu}$ in the Saint-Mandrier marina (STM) and 2.2 times higher for Mn along the breakwater that separates the Small Bay from the Large Bay (DLE), than in the three other sites. Because this pattern is consistent with water concentrations in $\mathrm{Cu}$ and $\mathrm{Mn}$ at all sites (Fig. 2), it is likely that local contamination levels for these elements at STM and DLE probably exceed the regulatory levels for juvenile fish.

On the contrary, $\mathrm{As}, \mathrm{Cr}, \mathrm{Hg}, \mathrm{Pb}$ and $\mathrm{V}$ are not essential for marine life and their concentrations in the organisms depend mainly on their environmental levels (Amiard et al., 1987). This is consistent with our findings for As and Cr: similar environmental contamination levels for these two elements at the four sites (Tessier et al., 2011) explain the absence of spatial variation in their concentrations in fish muscles. Similarly, the high $\mathrm{Pb}$ concentrations recorded in the muscle of both species at TLN are consistent with our measurement in the water column (Fig. 2), and with the high $\mathrm{Pb}$ contamination levels reported in the sediments of this area (Tessier et al., 2011). Therefore, the most likely explanation for the higher $\mathrm{V}$ concentrations measured in the flesh of the $D$. vulgaris juveniles captured at the STM site in 2015 is that of an accidental oil spill in this port, since V is one of the most abundant metals in petroleum (Ball et al., 1960). 
Unfortunately, technical constraints prevented us from measuring water concentrations for $\mathrm{Hg}$ during this study. However, the results for this element suggest that its contamination levels in ports are not directly reflected in fish flesh. Indeed, although $\mathrm{Hg}$ concentrations in the sediment have been reported to be 45 times higher at TLN than at MAG (Tessier et al., 2011), spatial variations for this metal in the muscle of the two species were surprisingly limited, and significant for D. vulgaris only. An explanation for this may lay in the role of food webs in the dynamics of metal accumulation. Indeed, food is a major route for metal uptake in fish, in particular $\mathrm{Hg}$ (e.g. Hall et al., 1997). Metals mainly enter the food chains through their uptake by the phytoplankton, their concentrations in this trophic compartment reflecting their specific uptake rates but also the phytoplankton growth (Blackmore and Wang, 2004). Processes of 'biomass dilution' in highly productive waters thus result in lower trace metal concentrations at the base of food webs (Cresson et al., 2015; Harmelin-Vivien et al., 2009). Because in this study, water Chl a concentrations were much higher at TLN and STM than at MAG and DLE, it is likely that high mean primary production in these two ports resulted in lower contamination of their phytoplankton by metals. This partially explains why spatial variation in fish $\mathrm{Hg}$ contamination levels were so limited, and probably contributed to the fact that fish muscle concentrations in $\mathrm{Pb}$ were higher at DLE than at STM when water concentrations for this metal suggested the opposite (Fig. 2). However, as copepods are the most common prey of Diplodus juveniles (Altin et al., 2015), the structure of the zooplankton community and its level of contamination also need to be considered when trying to explain fish contamination patterns. In the Bay of Toulon, zooplankton communities differ between the Large Bay and the Small Bay (Jamet et al., 2005) but the spatio-temporal fluctuations of their metal content are large and irregular (Rossi et al 2008). These fluctuations could explain the variations in fish contamination we observed, not only between the two years sampled, but also between the two species studied. Indeed, the seasons for fish presence on the juvenile habitats differ between $D$. vulgaris (winter/spring) and $D$. sargus (late spring/summer), with limited overlap between them. As a result, the higher $\mathrm{Cu}$ and $\mathrm{Pb}$ concentrations found in the flesh of $D$. sargus partially reflect the fact that highest concentrations in these two elements in the zooplankton are observed during the summer (Rossi and Jamet, 2008). 
Fish growth, body condition and health in ports

Body condition and growth are physiological indicators that have been regularly and successfully used to compare nursery habitat quality for fish (e.g. Amara et al., 2007; Gilliers et al., 2006; Isnard et al., 2015; Sogard and Able, 1992). The use of growth and condition as indices of habitat quality is based on the assumption that larger, faster growing fish are healthier and are hence exposed to more favorable environmental conditions than smaller slower-growing ones. For many juvenile fishes, the first winter is a critical period (Fullerton et al., 2000; Miranda and Hubbard, 1994), with severe conditions in the open-sea such as low temperatures, limited food resources and elevated risk of predation. Many studies have shown that fish that grow faster, or have higher levels of energy reserves, are less vulnerable to predation when they leave their juvenile habitats than those in poor condition; they also are more apt to survive the first winter of life and thereby contribute to the renewal of adult stocks (Biro et al., 2004; D'Alessandro et al., 2013; Sogard, 1997).

In Diplodus juveniles, growth and body condition of are mainly controlled by environmental parameters (Planes et al., 1999). In our study, post-settlement growth and final condition indexes were lower in D. vulgaris, which mostly occupies the juvenile habitats during the autumn and the winter, than in D. sargus, which occupies them during throughout the spring and the summer. Although interspecific differences in growth rates cannot be excluded, this confirms that temperature and food availability account significantly in the variation of juvenile growth and condition regardless of the juvenile habitat (Planes et al., 1999; Vigliola et al., 2000). Chemical contaminants also induce various biological responses in juvenile fish, affecting their physiology and their growth, but also their health and their behavior (e.g., Kerambrun et al., 2012; Laroche et al., 2002; Marchand et al., 2003; Rowe, 2003). As in other organisms, sub-lethal responses to contaminant exposure in fish commonly involve a decrease in feeding activity (Saborido-Rey et al., 2007; Stephens et al., 2000) and a modification in energy allocation, which is preferentially used to fight chemical stress rather than for body maintenance and growth (Rowe, 2003). This should have marked negative effects on both individual 
growth rate and body condition. However, spatial variations for these two parameters were limited in our study, and were not consistent between species or years. The significantly lower growth of $D$. sargus juveniles at TLN may be associated with the general exposure of their organisms to metal contaminants in this heavily polluted area, but, in general fish physiological status in this study seemed to be similar among all the sites studied, even if these included two heavily contaminated port sites (STM and TLN) and a natural nursery area under limited human influence (MAG). Therefore, environmental pollution seems to have a lesser influence than temperature or food availability on the growth and condition of Diplodus juveniles.

Although regularly used for evaluating fish health, growth rate and body condition are often less sensitive to environmental stressors than molecular biomarkers (Adams, 2002). Indeed, they both are subject to a variety of regulating influences, and are largely driven by water temperature and food abundance in juvenile fish (Planes et al., 1999). In our study area, high primary production in ports is probably the cause for substantial juvenile fish growth and condition despite pollution : by sustaining the development of zooplankton (Jamet et al., 2005) on which Diplodus juveniles feed (Altin et al., 2015), it reduces trophic competition and energy requirements for feeding, while the biodilution at the base of the food web that it induces probably lowers metal uptake by the fish. Both processes foster juvenile fish growth and condition and thereby offset the negative effects of chemical contaminants. However, the apparently low impact of local contamination on fish health in ports will need to be confirmed by investigations of fish physiological stress levels. Combining several molecular biomarkers (e.g. ethoxyresorufin-O-deethylase activity, glutathione S-transferase activity, catalase activity) for this should allow a comprehensive assessment of port environmental quality (Gilliers et al., 2006; Kerambrun et al., 2011; Vasconcelos et al., 2009).

Ports: potential nursery areas for coastal fishes?

The link between environmental pollution and juvenile fish contamination and health is not a straightforward one. During the last few years, certain studies have shown that the abundances of 
juveniles of the most common rocky species inside ports also seem to be similar to those found in natural habitats (Bouchoucha et al., 2016; Clynick, 2008; Dufour et al., 2009). These observations strongly suggest that ports could serve as nursery habitats at least for some rocky fishes, providing them with shelter and enhanced feeding conditions. This is all the more likely that our results unexpectedly showed that the condition and growth of Diplodus juveniles within highly polluted ports can be equivalent to those measured in nearby natural and artificial habitats that match the criteria for Diplodus spp. nursery grounds (Harmelin-Vivien et al., 1995; Pastor et al., 2013). Of course, our results will have to be confirmed for more fish species and other ports before reaching a general conclusion with regards to ports value as potential nursery areas for rocky fishes. Our results might also underestimate the actual impact of contaminants on fish juveniles in ports since the information gathered here is based only on survivors. Lastly, contaminants and their effects may accumulate over long periods of time prior to the onset of significant biological responses (Rowe, 2003). Therefore, for comprehensive assessment of the value of ports as nursery grounds, the impact of contaminant exposure during juvenile life (high and punctual or limited yet repeated) on the final mortality rates of fish and their capacity to reproduce will have to be explored. Investigations into the contribution of individuals that use ports as juvenile habitats to the adult stocks are also needed before one can reach a robust conclusion about the importance of ports in the maintenance of rocky fish stocks along anthropized shorelines.

\section{Acknowledgements}

This work was conducted within the framework of the RESPONSE Project funded by the 'Agence de l'Eau Rhône Mediterranée et Corse' and the Ifremer. We are grateful to N. Raventos Klein for her assistance for the otolith analyses. Thanks are also due to F. Chavanon, C. Ravel and A. Vion for their help during the laboratory work. 
Literature cited

Abecasis, D., Bentes, L., Erzini, K., 2009. Home range, residency and movements of Diplodus sargus and Diplodus vulgaris in a coastal lagoon: Connectivity between nursery and adult habitats. Estuarine Coastal and Shelf Science 85, 525-529.

Able, K.W., Manderson, J.P., Studholme, A.L., 1999. Habitat quality for shallow water fishes in an urban estuary: the effects of man-made structures on growth. Mar. Ecol.-Prog. Ser. 187, 227-235. Adamo, P., Arienzo, M., Imperato, M., Naimo, D., Nardi, G., Stanzione, D., 2005. Distribution and partition of heavy metals in surface and sub-surface sediments of Naples city port. Chemosphere 61, 800-809.

Adams, S.M., 2002. Biological indicators of aquatic ecosystem stress. American Fisheries Society, Bethesda, Maryland.

Altin, A., Ozen, O., Ayyildiz, H., Ayaz, A., 2015. Feeding habits and diet overlap of juveniles of 2 sparids, Diplodus puntazzo (Walbaum, 1792) and Diplodus vulgaris (Geoffroy Saint-Hilaire, 1817), from the North Aegean Sea of Turkey. Turk. J. Zool. 39, 80-87.

Amara, R., Méziane, T., Gilliers, C., Hermel, G., Laffargue, P., 2007. Growth and condition indices measured on juvenile sole (Solea solea L.) to assess the quality of essential fish habitat. Mar. Ecol.Prog. Ser. 351, 201-208.

Amiard, J.C., Amiardtriquet, C., Berthet, B., Metayer, C., 1987. Comparative study of the patterns of bioaccumulation of essential $(\mathrm{Cu}, \mathrm{Zn})$ and non-essential $(\mathrm{Cd}, \mathrm{Pb})$ trace metals in various estuarine and coastal organisms. Journal of Experimental Marine Biology and Ecology 106, 73-89.

Anderson, J.M., 2001. Permutation tests for univariate or multivariate analysis of variance and regression. Canadian Journal of Fisheries and Aquatic Sciences 58, 626-639.

Ball, J.S., Wenger, W.J., Hyden, H.J., Horr, C.A., Myers, A.T., 1960. Metal Content of Twenty-Four Petroleums. Journal of Chemical \& Engineering Data 5, 553-557.

Beck, M.W., Heck, K.L., Able, K.W., Childers, D.L., Eggleston, D.B., Gillanders, B.M., Halpern, B., Hays, C.G., Hoshino, K., Minello, T.J., Orth, R.J., Sheridan, P.F., Weinstein, M.R., 2001. The identification, conservation, and management of estuarine and marine nurseries for fish and invertebrates.

Bioscience 51, 633-641.

Biro, P.A., Morton, A.E., Post, J.R., Parkinson, E.A., 2004. Over-winter lipid depletion and mortality of age-0 rainbow trout (Oncorhynchus mykiss). Canadian Journal of Fisheries and Aquatic Sciences 61, 1513-1519.

Blackmore, G., Wang, W.X., 2004. The transfer of cadmium, mercury, methylmercury, and zinc in an intertidal rocky shore food chain. Journal of Experimental Marine Biology and Ecology 307, 91-110. Bouchoucha, M., Darnaude, A.M., Gudefin, A., Neveu, R., Verdoit-Jarraya, M., Boissery, P., Lenfant, P., 2016. Potential use of marinas as nursery grounds by rocky fishes: insights from four Diplodus species in the Mediterranean. Mar. Ecol.-Prog. Ser. 547, 193-209.

Campana, S.E., 1999. Chemistry and composition of fish otoliths: pathways, mechanisms and applications. Mar. Ecol.-Prog. Ser. 188, 263-297.

Campana, S.E., Jones, C.M., 1992. Analysis of otolith microstructure data. Canadian Special

Publication of Fisheries and Aquatic Sciences, 73-73.

Campana, S.E., Thorrold, S.R., 2001. Otoliths, increments, and elements: keys to a comprehensive understanding of fish populations? Canadian Journal of Fisheries and Aquatic Sciences 58, 30-38.

Carassou, L., Mellin, C., Ponton, D., 2009. Assessing the diversity and abundances of larvae and juveniles of coral reef fish: a synthesis of six sampling techniques. Biodivers. Conserv. 18, 355-371. Chapman, D.V., 1996. Water quality assessments: a guide to the use of biota, sediments, and water in environmental monitoring. $E$ \& Fn Spon London.

Cheminee, A., Francour, P., Harmelin-Vivien, M., 2011. Assessment of Diplodus spp. (Sparidae) nursery grounds along the rocky shore of Marseilles (France, NW Mediterranean). Scientia Marina 75, 181-188. 
Cheminee, A., Sala, E., Pastor, J., Bodilis, P., Thiriet, P., Mangialajo, L., Cottalorda, J.-M., Francour, P., 2013. Nursery value of Cystoseira forests for Mediterranean rocky reef fishes. Journal of Experimental Marine Biology and Ecology 442, 70-79.

Chouvelon, T., Brach-Papa, C., Auger, D., Bodin, N., Bruzac, S., Crochet, S., Degroote, M., Hollanda, S.J., Hubert, C., Knoery, J., Munschy, C., Puech, A., Rozuel, E., Thomas, B., West, W., Bourjea, J., Nikolic, N., 2017. Chemical contaminants (trace metals, persistent organic pollutants) in albacore tuna from western Indian and south-eastern Atlantic Oceans: Trophic influence and potential as tracers of populations. Science of The Total Environment 596, 481-495.

Clarke, K.R., Warwick, R.M., 2001. Change in marine communities: an approach to statistical analysis and interpretation. PRIMER-E Limited Plymouth, UK.

Clynick, B.G., 2006. Assemblages of fish associated with coastal marinas in north-western Italy. Journal of the Marine Biological Association of the United Kingdom 86, 847-852.

Clynick, B.G., 2008. Characteristics of an urban fish assemblage: Distribution of fish associated with coastal marinas. Marine Environmental Research 65, 18-33.

Coll, J., Linde, M., García-Rubies, A., Riera, F., Grau, A.M., 2004. Spear fishing in the Balearic Islands (west central Mediterranean): species affected and catch evolution during the period 1975-2001. Fisheries Research 70, 97-111.

Cossa, D., Harmelin-Vivien, M., Mellon-Duval, C., Loizeau, V., Averty, B., Crochet, S., Chou, L., Cadiou, J.-F., 2012. Influences of bioavailability, trophic position, and growth on methylmercury in hakes (Merluccius merluccius) from northwestern Mediterranean and northeastern Atlantic. Environ. Sci. Technol. 46, 4885-4893.

Courrat, A., Lobry, J., Nicolas, D., Laffargue, P., Amara, R., Lepage, M., Girardin, M., Le Pape, O., 2009. Anthropogenic disturbance on nursery function of estuarine areas for marine species. Estuarine Coastal and Shelf Science 81, 179-190.

Cresson, P., Bouchoucha, M., Miralles, F., Elleboode, R., Mahe, K., Marusczak, N., Thebault, H., Cossa, D., 2015. Are red mullet efficient as bio-indicators of mercury contamination? A case study from the French Mediterranean. Mar. Pollut. Bull. 91, 191-199.

Cresson, P., Fabri, M.C., Bouchoucha, M., Papa, C.B., Chavanon, F., Jadaud, A., Knoery, J., Miralles, F., Cossa, D., 2014. Mercury in organisms from the Northwestern Mediterranean slope: Importance of food sources. Science of The Total Environment 497, 229-238.

D'Alessandro, E.K., Sponaugle, S., Cowen, R.K., 2013. Selective mortality during the larval and juvenile stages of snappers (Lutjanidae) and great barracuda Sphyraena barracuda. Mar. Ecol.-Prog. Ser. 474, 227-242.

Dang, D.H., Schafer, J., Brach-Papa, C., Lenoble, V., Durrieu, G., Dutruch, L., Chiffoleau, J.F., Gonzalez, J.L., Blanc, G., Mullot, J.U., Mounier, S., Garnier, C., 2015. Evidencing the Impact of Coastal Contaminated Sediments on Mussels Through Pb Stable Isotopes Composition. Environ. Sci. Technol. 49, 11438-11448.

Darbra, R.M., Ronza, A., Casal, J., Stojanovic, T.A., Wooldridge, C., 2004. The Self Diagnosis Method A new methodology to assess environmental management in sea ports. Mar. Pollut. Bull. 48, 420-

428.

Darbra, R.M., Ronza, A., Stojanovic, T.A., Wooldridge, C., Casal, J., 2005. A procedure for identifying significant environmental aspects in sea ports. Mar. Pollut. Bull. 50, 866-874.

Das, A.K., 2000. Trace metal status in marine biological samples: a review. Int. J. Environ. Pollut. 13, 208-225.

Davison, W., Zhang, H., 1994. In situspeciation measurements of trace components in natural waters using thin-film gels. Nature 367, 546-548.

Di Franco, A., De Benedetto, G., De Rinaldis, G., Raventos, N., Sahyoun, R., Guidetti, P., 2011. Large scale-variability in otolith microstructure and microchemistry: The case study of Diplodus sargus sargus (Pisces: Sparidae) in the Mediterranean Sea. Italian Journal of Zoology 78, 182-192. Doherty, P.P., 1981. Coral reef fishes: recruitment-limited assemblages?, The Reef and Man. Proceedings of the 4th International Coral Reef Symposium, Manila Philippines, 18-22 May 1981pages: 2: 465-470. Marine Sciences Center, University of the Philippines. 
Dufour, V., Cantou, M., Lecomte, F., 2009. Identification of sea bass (Dicentrarchus labrax) nursery areas in the north-western Mediterranean Sea. Journal of the Marine Biological Association of the United Kingdom 89, 1367-1374.

Dufresne, C., Duffa, C., Rey, V., 2014. Wind-forced circulation model and water exchanges through the channel in the Bay of Toulon. Ocean Dyn. 64, 209-224.

Franco, A., Franzoi, P., Malavasi, S., Riccato, F., Torricelli, P., Mainardi, D., 2006. Use of shallow water habitats by fish assemblages in a Mediterranean coastal lagoon. Estuarine Coastal and Shelf Science 66, 67-83.

Francour, P., 1999. A critical review of adult and juvenile fish sampling techniques in Posidonia oceanica seagrass beds. Naturalista sicil 23, 33-57.

Fullerton, A.H., Garvey, J.E., Wright, R.A., Stein, R.A., 2000. Overwinter growth and survival of largemouth bass: Interactions among size, food, origin, and winter severity. Transactions of the American Fisheries Society 129, 1-12.

García-Rubies, A., Macpherson, E., 1995. Substrate use and temporal pattern of recruitment in juvenile fishes of the Mediterranean littoral. Mar. Biol. 124, 35-42.

Gibson, R., 1994. Impact of habitat quality and quantity on the recruitment of juvenile flatfishes.

Netherlands Journal of Sea Research 32, 191-206.

Gilliers, C., Le Pape, O., Desaunay, Y., Morin, J., Guerault, D., Amara, R., 2006. Are growth and density quantitative indicators of essential fish habitat quality? An application to the common sole Solea solea nursery grounds. Estuarine Coastal and Shelf Science 69, 96-106.

Guidetti, P., 2004. Fish assemblages associated with coastal defence structures in south-western Italy (Mediterranean Sea). Journal of the Marine Biological Association of the United Kingdom 84, 669670.

Hall, B.D., Bodaly, R.A., Fudge, R.J.P., Rudd, J.W.M., Rosenberg, D.M., 1997. Food as the dominant pathway of methylmercury uptake by fish. Water Air and Soil Pollution 100, 13-24.

Harmelin-Vivien, M., Cossa, D., Crochet, S., Banaru, D., Letourneur, Y., Mellon-Duval, C., 2009.

Difference of mercury bioaccumulation in red mullets from the north-western Mediterranean and Black seas. Mar. Pollut. Bull. 58, 679-685.

Harmelin-Vivien, M.L., Harmelin, J.G., Leboulleux, V., 1995. Microhabitat requirements for settlement of juvenile sparid fishes on Mediterranean rocky shores. Hydrobiologia 300-301, 309-320.

Henry, F., Amara, R., Courcot, L., Lacouture, D., Bertho, M.L., 2004. Heavy metals in four fish species from the French coast of the eastern English Channel and Southern Bight of the North Sea. Environ. Int. 30, 675-683.

Isnard, E., Tournois, J., McKenzie, D.J., Ferraton, F., Bodin, N., Aliaume, C., Darnaude, A.M., 2015. Getting a Good Start in Life? A Comparative Analysis of the Quality of Lagoons as Juvenile Habitats for the Gilthead Seabream Sparus aurata in the Gulf of Lions. Estuaries and Coasts 38, 1937-1950. Jamet, J.L., Jean, N., Boge, G., Richard, S., Jamet, D., 2005. Plankton succession and assemblage structure in two neighbouring littoral ecosystems in the north-west Mediterranean Sea. Mar. Freshw. Res. 56, 69-83.

Jean, N., Dumont, E., Durrieu, G., Balliau, T., Jamet, J.L., Personnic, S., Garnier, C., 2012. Protein expression from zooplankton communities in a metal contaminated NW mediterranean coastal ecosystem. Marine Environmental Research 80, 12-26.

Jennings, S., Blanchard, J.L., 2004. Fish abundance with no fishing: predictions based on macroecological theory. Journal of Animal Ecology 73, 632-642.

Jones, C.L., Anderson, T.W., Edwards, M.S., 2013. Evaluating eelgrass site quality by the settlement, performance, and survival of a marine fish. Journal of Experimental Marine Biology and Ecology 445, 61-68.

Kerambrun, E., Henry, F., Cornille, V., Courcot, L., Amara, R., 2013. A combined measurement of metal bioaccumulation and condition indices in juvenile European flounder, Platichthys flesus, from European estuaries. Chemosphere 91, 498-505. 
Kerambrun, E., Henry, F., Courcot, L., Gevaert, F., Amara, R., 2012. Biological responses of caged juvenile sea bass (Dicentrarchus labrax) and turbot (Scophtalmus maximus) in a polluted harbour. Ecological Indicators 19, 161-171.

Kerambrun, E., Sanchez, W., Henry, F., Amara, R., 2011. Are biochemical biomarker responses related to physiological performance of juvenile sea bass (Dicentrarchus labrax) and turbot (Scophthalmus maximus) caged in a polluted harbour? Comparative Biochemistry and Physiology C-Toxicology \& Pharmacology 154, 187-195.

Laroche, J., Quiniou, L., Juhel, G., Auffret, M., Moraga, D., 2002. Genetic and physiological responses of flounder (Platichthys flesus) populations to chemical contamination in estuaries. Environ. Toxicol. Chem. 21, 2705-2712.

Lloret, J., Zaragoza, N., Caballero, D., Font, T., Casadevall, M., Riera, V., 2008. Spearfishing pressure on fish communities in rocky coastal habitats in a Mediterranean marine protected area. Fisheries Research 94, 84-91.

MacPherson, E., 1998. Ontogenetic shifts in habitat use and aggregation in juvenile sparid fishes. Journal of Experimental Marine Biology and Ecology 220, 127-150.

Macpherson, E., Biagi, F., Francour, P., Garcia-Rubies, A., Harmelin, J., Harmelin-Vivien, M., Jouvenel, J.Y., Planes, S., Vigliola, L., Tunesi, L., 1997. Mortality of juvenile fishes of the genus Diplodus in protected and unprotected areas in the western Mediterranean Sea. Mar. Ecol.-Prog. Ser. 160, 135147.

Marchand, J., Tanguy, A., Laroche, J., Quiniou, L., Moraga, D., 2003. Responses of European flounder Platichthys flesus populations to contamination in different estuaries along the Atlantic coast of France. Mar. Ecol.-Prog. Ser. 260, 273-284.

Miranda, L.E., Hubbard, W.D., 1994. Length-dependant winter survival and lipid composition of age-0 largemouth bass in Bay Springs Reservoir, Mississipi. Transactions of the American Fisheries Society $123,80-87$.

Morales-Nin, B., Moranta, J., García, C., Tugores, M.P., Grau, A.M., Riera, F., Cerdà, M., 2005. The recreational fishery off Majorca Island (western Mediterranean): some implications for coastal resource management. ICES Journal of Marine Science: Journal du Conseil 62, 727-739.

Nagelkerken, I., Faunce, C.H., 2008. What makes mangroves attractive to fish? Use of artificial units to test the influence of water depth, cross-shelf location, and presence of root structure. Estuarine Coastal and Shelf Science 79, 559-565.

Nakhle, K., Cossa, D., Claisse, D., Beliaeff, B., Simon, S., 2007. Cadmium and mercury in Seine Estuary flounders and mussels: the results of two decades of monitoring. Ices Journal of Marine Science 64, 929-938.

Neveux, J., Lantoine, F., 1993. Spectrofluorometric assay of chlorophylls and phaeopigments using the least squares approximation technique. Deep Sea Research Part I: Oceanographic Research Papers 40, 1747-1765.

Nicolau, R., Lucas, Y., Merdy, P., Raynaud, M., 2012. Base flow and stormwater net fluxes of carbon and trace metals to the Mediterranean sea by an urbanized small river. water research 46, 66256637.

Odzak, N., Kistler, D., Xue, H., Sigg, L., 2002. In situ trace metal speciation in a eutrophic lake using the technique of diffusion gradients in thin films (DGT). Aquatic Sciences-Research Across Boundaries 64, 292-299.

Panfili, J., 2002. Manual of fish sclerochronology. Ifremer IRD coédition, Brest - France.

Pannella, G., 1971. Fish Otoliths: Daily Growth Layers and Periodical Patterns. Science 173, 11241127.

Pastor, J., Koeck, B., Astruch, P., Lenfant, P., 2013. Coastal man-made habitats: Potential nurseries for an exploited fish species, Diplodus sargus (Linnaeus, 1758). Fisheries Research 148, 74-80.

Pizzolon, M., Cenci, E., Mazzoldi, C., 2008. The onset of fish colonization in a coastal defence structure (Chioggia, Northern Adriatic Sea). Estuarine Coastal and Shelf Science 78, 166-178.

Planes, S., Macpherson, E., Biagi, F., Garcia-Rubies, A., Harmelin, J., Harmelin-Vivien, M., Jouvenel, J.Y., Tunesi, L., Vigliola, L., Galzin, R., 1999. Spatio-temporal variability in growth of juvenile sparid 
fishes from the Mediterranean littoral zone. Journal of the Marine Biological Association of the United Kingdom 79, 137-143.

Pougnet, F., Schafer, J., Dutruch, L., Garnier, C., Tessier, E., Dang, D.H., Lanceleur, L., Mullot, J.U., Lenoble, V., Blanc, G., 2014. Sources and historical record of tin and butyl-tin species in a Mediterranean bay (Toulon Bay, France). Environmental Science and Pollution Research 21, 66406651.

Ricker, W.E., 1975. Computation and interpretation of biological statistics of fish populations. Dept. of Fisheries and Oceans, Ottawa.

Rossi, N., Jamet, J.L., 2008. In situ heavy metals (copper, lead and cadmium) in different plankton compartments and suspended particulate matter in two coupled Mediterranean coastal ecosystems (Toulon Bay, France). Mar. Pollut. Bull. 56, 1862-1870.

Rowe, C.L., 2003. Growth responses of an estuarine fish exposed to mixed trace elements in sediments over a full life cycle. Ecotox. Environ. Safe. 54, 229-239.

Ruitton, S., Francour, P., Boudouresque, C.F., 2000. Relationships between algae, benthic herbivorous invertebrates and fishes in rocky sublittoral communities of a temperate sea (Mediterranean). Estuarine Coastal and Shelf Science 50, 217-230.

Saborido-Rey, F., Dominguez-Petit, R., Tomas, J., Morales-Nin, B., Alonso-Fernandez, A., 2007. Growth of juvenile turbot in response to food pellets contaminated by fuel oil from the tanker 'Prestige'. Mar. Ecol.-Prog. Ser. 345, 271-279.

Schintu, M., Degetto, S., 1999. Sedimentary records of heavy metals in the industrial harbour of Portovesme, Sardinia (Italy). Science of The Total Environment 241, 129-141.

Schintu, M., Marrucci, A., Marras, B., Galgani, F., Buosi, C., Ibba, A., Cherchi, A., 2016. Heavy metal accumulation in surface sediments at the port of Cagliari (Sardinia, western Mediterranean): Environmental assessment using sequential extractions and benthic foraminifera. Mar. Pollut. Bull. $111,45-56$.

Sogard, S.M., 1997. Size-selective mortality in the juvenile stage of teleost fishes: A review. Bulletin of Marine Science 60, 1129-1157.

Sogard, S.M., Able, K.W., 1992. Growth variation of newly settled winter flounder

(Pseudopleuronectes americanus) in New-Jersey estuaries as determined by otolith microstructure. Netherlands Journal of Sea Research 29, 163-172.

Stephens, S.M., Frankling, S.C., Stagg, R.M., Brown, J.A., 2000. Sub-lethal effects of exposure of juvenile turbot to oil produced water. Mar. Pollut. Bull. 40, 928-937.

Tessier, E., Garnier, C., Mullot, J.U., Lenoble, V., Arnaud, M., Raynaud, M., Mounier, S., 2011. Study of the spatial and historical distribution of sediment inorganic contamination in the Toulon bay

(France). Mar. Pollut. Bull. 62, 2075-2086.

Tortonese, E., 1965. Biologie comparée de trois espèces méditerranéennes de Diplodus (Pisces Sparidae). Rapport Commission International pour l'Exploration Scientifique de la Mer Méditérranée 189-192.

Twiss, M.R., Moffett, J.W., 2002. Comparison of copper speciation in coastal marine waters measured using analytical voltammetry and diffusion gradient in thin-film techniques. Environ. Sci. Technol. 36, 1061-1068.

Vallee, B.L., Auld, D.S., 1990. Zinc coordination, function, and structure of zinc enzymes and other proteins. Biochemistry 29, 5647-5659.

Vasconcelos, R.P., Reis-Santos, P., Fonseca, V., Ruano, M., Tanner, S., Costa, M.J., Cabral, H.N., 2009. Juvenile fish condition in estuarine nurseries along the Portuguese coast. Estuarine Coastal and Shelf Science 82, 128-138.

Vasconcelos, R.P., Reis-Santos, P., Maia, A., Ruano, M., Costa, M.J., Cabral, H.N., 2011. Trace metals $(\mathrm{Cu}, \mathrm{Zn}, \mathrm{Cd}$ and $\mathrm{Pb})$ in juvenile fish from estuarine nurseries along the Portuguese coast. Scientia Marina 75, 155-162.

Vasconcelos, R.P., Reis-Santos, P., Tanner, S., Maia, A., Latkoczy, C., Gunther, D., Costa, M.J., Cabral, H., 2008. Evidence of estuarine nursery origin of five coastal fish species along the Portuguese coast through otolith elemental fingerprints. Estuarine Coastal and Shelf Science 79, 317-327. 
Ventura, D., Jona Lasinio, G., Ardizzone, G., 2014. Temporal partitioning of microhabitat use among four juvenile fish species of the genus Diplodus (Pisces: Perciformes, Sparidae). Marine Ecology, 1-20. Vigliola, L., 1997. Validation of daily increment formation in otoliths for three Diplodus species in the Mediterranean sea. Journal of Fish Biology 51, 349-360.

Vigliola, L., Harmelin-Vivien, M., 2001. Post-settlement ontogeny in three Mediterranean reef fish species of the genus Diplodus. Bulletin of Marine Science 68, 271-286.

Vigliola, L., Harmelin-Vivien, M., Meekan, M.G., 2000. Comparison of techniques of back-calculation of growth and settlement marks from the otoliths of three species of Diplodus from the Mediterranean Sea. Canadian Journal of Fisheries and Aquatic Sciences 57, 1291-1299.

Vigliola, L., Harmelin-Vivien, M.L., Biagi, F., Galzin, R., Garcia-Rubies, A., Harmelin, J.G., Jouvenel, J.Y., Le Direach-Boursier, L., Macpherson, E., Tunesi, L., 1998. Spatial and temporal patterns of settlement among sparid fishes of the genus Diplodus in the northwestern Mediterranean. Mar. Ecol.-Prog. Ser. $168,45-56$.

Vinagre, C., Cabral, H.N., Costa, M.J., 2010. Relative importance of estuarine nurseries for species of the genus Diplodus (Sparidae) along the Portuguese coast. Estuarine Coastal and Shelf Science 86, 197-202.

Wafo, E., Abou, L., Nicolay, A., Boissery, P., Perez, T., Abondo, R.N., Garnier, C., Chacha, M., Portugal, H., 2016. A chronicle of the changes undergone by a maritime territory, the Bay of Toulon (Var Coast, France), and their consequences on PCB contamination. SpringerPlus 5.

Wilson, J.A., Vigliola, L., Meekan, M.G., 2009. The back-calculation of size and growth from otoliths: Validation and comparison of models at an individual level. Journal of Experimental Marine Biology and Ecology 368, 9-21.

Zhang, H., Davison, W., 2001. In situ speciation measurements. Using diffusive gradients in thin films (DGT) to determine inorganically and organically complexed metals. Pure and Applied Chemistry 73, 9-15.

Zhang, H., Davison, W., Miller, S., Tych, W., 1995. In situ high resolution measurements of fluxes of $\mathrm{Ni}, \mathrm{Cu}, \mathrm{Fe}$, and $\mathrm{Mn}$ and concentrations of $\mathrm{Zn}$ and $\mathrm{Cd}$ in porewaters by DGT. Geochimica Et Cosmochimica Acta 59, 4181-4192. 


\section{Tables}

Table 1: Environmental parameters for the four sampling sites studied, inside (STM and TLN) and outside (DLE and MAG) ports in the Bay of Toulon.

\begin{tabular}{ccccccc}
\hline & \multicolumn{2}{c}{ Mean temperature $\left({ }^{\circ} \mathrm{C}\right)$} & \multicolumn{2}{c}{ Mean salinity } & \multicolumn{2}{c}{$\begin{array}{c}\text { Mean Chloropyll a } \\
\text { concentration }\left(\mu \mathrm{gg} . \mathrm{l}^{-1}\right)\end{array}$} \\
\cline { 2 - 7 } site & $\begin{array}{c}\text { mean } \pm \\
\text { SD }\end{array}$ & min-max & $\begin{array}{c}\text { mean } \pm \\
\text { SD }\end{array}$ & min-max & mean $\pm \mathrm{SD}$ & min-max \\
\hline DLE & $17.1 \pm 3.9$ & $12.6-23.6$ & $38.0 \pm 0.8$ & $35.8-39.0$ & $0.27 \pm 0.17$ & $0.02-0.58$ \\
MAG & $17.4 \pm 4.1$ & $13.2-25.5$ & $38.0 \pm 0.5$ & $37.2-39.1$ & $0.27 \pm 0.20$ & $0.13-0.86$ \\
STM & $17.7 \pm 4.9$ & $12.0-25.4$ & $37.8 \pm 1.3$ & $34.4-39.5$ & $0.37 \pm 0.23$ & $0.16-0.80$ \\
TLN & $17.5 \pm 4.3$ & $12.8-24.8$ & $37.7 \pm 1.0$ & $35.1-38.8$ & $0.48 \pm 0.33$ & $0.17-1.16$ \\
\hline
\end{tabular}


Table 2: Growth and body condition (mean $\pm \mathrm{SD}$ ) of the juveniles of $D$. sargus and D. vulgaris at the four sampling sites studied, inside (STM and TLN) and outside (DLE and MAG) ports in the Bay of Toulon.

\begin{tabular}{|c|c|c|c|c|c|c|}
\hline & Site & $\begin{array}{l}\text { Total length } \\
(\mathrm{mm})\end{array}$ & Total mass $(\mathrm{g})$ & $\begin{array}{c}\text { Total age } \\
\text { (day) }\end{array}$ & $\begin{array}{l}\text { Absolute growth } \\
\text { rate }\left(\mu \text { m.day }^{-1}\right)\end{array}$ & Fulton's K \\
\hline D. sargus & $\operatorname{DLE}(\mathrm{n}=10)$ & $60.6 \pm 12.3$ & $4.4 \pm 2.6$ & $125.9 \pm 28.5$ & $6.8 \pm 0.9$ & $1.74 \pm 0.13$ \\
\hline \multirow[t]{3}{*}{ Year $=2014$} & MAG $(n=16)$ & $70.0 \pm 9.3$ & $6.4 \pm 2.3$ & $139.3 \pm 15.8$ & $6.9 \pm 0.9$ & $1.79 \pm 0.10$ \\
\hline & $\operatorname{STM}(\mathrm{n}=12)$ & $66.7 \pm 7.4$ & $5.5 \pm 1.7$ & $145.8 \pm 16.9$ & $6.5 \pm 0.6$ & $1.81 \pm 0.06$ \\
\hline & TLN (n=14) & $59.0 \pm 4.3$ & $3.8 \pm 0.8$ & $132.3 \pm 10.2$ & $6.1 \pm 0.7$ & $1.83 \pm 0.10$ \\
\hline D. vulgaris & $\operatorname{DLE}(\mathrm{n}=10)$ & $57.9 \pm 9.6$ & $3.1 \pm 1.6$ & $173.9 \pm 15.3$ & $4.6 \pm 0.7$ & $1.44 \pm 0.12$ \\
\hline \multirow[t]{3}{*}{ Year $=2014$} & MAG $(n=10)$ & $57.2 \pm 10.9$ & $3.2 \pm 2.1$ & $192.4 \pm 17.9$ & $4.3 \pm 0.8$ & $1.52 \pm 0.21$ \\
\hline & $\mathrm{STM}(\mathrm{n}=10)$ & $62.6 \pm 9.0$ & $4.1 \pm 2.1$ & $188.5 \pm 31.9$ & $4.7 \pm 0.6$ & $1.57 \pm 0.12$ \\
\hline & TLN (n=13) & $64.3 \pm 10.3$ & $4.2 \pm 2.1$ & $192 \pm 13.4$ & $4.8 \pm 1.0$ & $1.46 \pm 0.05$ \\
\hline D. vulgaris & DLE $(n=9)$ & $59.4 \pm 8.3$ & $3.5 \pm 1.5$ & $169.3 \pm 18.0$ & $5.6 \pm 0.6$ & $1.58 \pm 0.08$ \\
\hline \multirow[t]{3}{*}{ Year $=2015$} & MAG (n=3) & $59.3 \pm 2.1$ & $3.6 \pm 0.6$ & $165.7 \pm 12.7$ & $5.5 \pm 0.3$ & $1.71 \pm 0.17$ \\
\hline & $\mathrm{STM}(\mathrm{n}=11)$ & $58.1 \pm 7.5$ & $3.2 \pm 1.3$ & $184.8 \pm 10.8$ & $5.2 \pm 0.8$ & $1.58 \pm 0.12$ \\
\hline & $\operatorname{TLN}(n=9)$ & $65.3 \pm 6.4$ & $4.8 \pm 1.4$ & $178.3 \pm 7.0$ & $5.4 \pm 0.4$ & $1.69 \pm 0.10$ \\
\hline
\end{tabular}


Table 3: Trace metal concentrations (in $\mathrm{m} \mathrm{kg}^{-1} \mathrm{dm}$ ) measured in fish muscle tissue at each site (DLE, MAG, STM and TLN)

\begin{tabular}{|c|c|c|c|c|c|c|c|c|c|c|c|c|}
\hline \multirow[b]{3}{*}{$\begin{array}{l}\text { D. Sargus } \\
2014\end{array}$} & \multicolumn{2}{|c|}{$\mathbf{A} \mathbf{l}\left(m g \cdot k g^{-1} d m\right)$} & \multicolumn{2}{|c|}{$\mathbf{T i}\left(m g . k g^{-1} d m\right)$} & \multicolumn{2}{|c|}{$\mathbf{V}\left(m g . k g^{-1} d m\right)$} & \multicolumn{2}{|c|}{$\mathbf{C r}\left(m g . k g^{-1} d m\right)$} & \multicolumn{2}{|c|}{$\operatorname{Mn}\left(m g \cdot k g^{-1} d m\right)$} & \multicolumn{2}{|c|}{$\mathbf{F e}\left(m g \cdot k g^{-1} d m\right)$} \\
\hline & Mean \pm sd & Min - Max & Mean \pm sd & Min - Max & Mean \pm sd & $\begin{array}{l}\text { Min - } \\
\text { Max }\end{array}$ & Mean \pm sd & $\begin{array}{l}\text { Min - } \\
\text { Max } \\
\end{array}$ & Mean \pm sd & $\begin{array}{l}\text { Min - } \\
\text { Max }\end{array}$ & Mean $\pm \mathrm{sd}$ & Min - Max \\
\hline & & & & & & & & & & & & \\
\hline $\operatorname{DLE}(n=5)$ & $3.5 \pm 1.5$ & $1.6-5.4$ & $6.9 \pm 1.3$ & $5.4-8.2$ & $0.10 \pm 0.06$ & $0.00-0.13$ & $0.34 \pm 0.40$ & $0.1-1.0$ & $0.91 \pm 0.13$ & $0.82-1.1$ & $11 \pm 2.3$ & $8.9-15$ \\
\hline MAG $(n=5)$ & $2.8 \pm 2.0$ & $1.4-6.3$ & $7.8 \pm 1.5$ & $6.3-10$ & $0.20 \pm 0.06$ & $0.13-0.27$ & $0.21 \pm 0.17$ & $0.00-0.47$ & $0.74 \pm 0.10$ & $0.64-0.87$ & $15 \pm 1.8$ & $14-18$ \\
\hline STM $(n=5)$ & $6.6 \pm 3.5$ & $2.7-10.1$ & $9.9 \pm 2.3$ & $5.7-13$ & $0.20 \pm 0.04$ & $0.13-0.25$ & $0.34 \pm 0.38$ & $0.14-1.0$ & $0.70 \pm 0.09$ & $0.55-0.79$ & $22 \pm 11$ & $13-41$ \\
\hline $\begin{array}{l}\quad \text { TLN }(\mathrm{n}=5) \\
\text { D. vulgaris } \\
\text { 2014 }\end{array}$ & $3.9 \pm 2.1$ & $2.0-7.3$ & $11 \pm 5.6$ & $5.6-21$ & $0.34 \pm 0.08$ & $0.22-0.43$ & $0.28 \pm 0.21$ & $0.12-0.61$ & $0.64 \pm 0.07$ & $0.55-0.71$ & $15 \pm 3.8$ & $11-19$ \\
\hline DLE $(n=4)$ & $3.5 \pm 0.8$ & $2.5-4.2$ & $11 \pm 2.6$ & $7.1-13$ & $0.58 \pm 0.25$ & $0.35-0.88$ & $1.5 \pm 1.6$ & $0.58-3.9$ & $1.7 \pm 0.98$ & $0.92-3.1$ & $18 \pm 4.5$ & $14-24$ \\
\hline MAG $(n=5)$ & $7.2 \pm 2.4$ & $4.1-10.5$ & $13 \pm 4.2$ & $7.9-18$ & $0.53 \pm 0.09$ & $0.43-0.63$ & $0.65 \pm 0.42$ & $0.27-1.4$ & $1.1 \pm 0.57$ & $0.80-2.1$ & $19 \pm 4.1$ & $14-25$ \\
\hline $\operatorname{STM}(n=4)$ & $3.9 \pm 1.6$ & $1.8-5.4$ & $6.8 \pm 4.2$ & $1.7-11$ & $1.2 \pm 0.81$ & $0.48-2.4$ & $0.83 \pm 0.59$ & $0.40-1.7$ & $0.71 \pm 0.31$ & $0.46-1.1$ & $14 \pm 9$ & $1.6-22$ \\
\hline $\begin{array}{l}\quad \text { TLN }(\mathrm{n}=4) \\
\text { D. vulgaris } \\
\text { 2015 }\end{array}$ & $11 \pm 7.6$ & $6.1-22$ & $7.8 \pm 0.90$ & $7.3-9.2$ & $0.43 \pm 0.07$ & $0.39-0.54$ & $0.43 \pm 0.10$ & $0.32-0.56$ & $0.85 \pm 0.04$ & $0.80-0.89$ & $18 \pm 3.8$ & $15-24$ \\
\hline DLE $(n=5)$ & $16 \pm 26$ & $1.4-62$ & $13 \pm 3.2$ & $10-18$ & $1.1 \pm 0.68$ & $0.63-2.3$ & $0.43 \pm 0.87$ & $0.00-2.0$ & $2.9 \pm 1.12$ & $1.9-4.5$ & $29 \pm 26$ & $7.0-64$ \\
\hline MAG $(n=3)$ & $1.2 \pm 0.20$ & $1.0-1.4$ & $14 \pm 3.6$ & $12-18$ & $1.0 \pm 0.28$ & $0.77-1.3$ & $0.13 \pm 0.14$ & $0.00-0.29$ & $1.4 \pm 0.04$ & $1.4-1.5$ & $16 \pm 7.5$ & $10-24$ \\
\hline $\operatorname{STM}(n=5)$ & $22 \pm 20$ & $7.0-57$ & $16 \pm 3.4$ & $12-20$ & $2.0 \pm 0.89$ & $1.32-3.6$ & $0.15 \pm 0.10$ & $0.00-0.28$ & $1.1 \pm 0.20$ & $0.87-1.3$ & $25 \pm 12$ & $15-45$ \\
\hline $\operatorname{TLN}(\mathrm{n}=6)$ & $2.3 \pm 0.80$ & $1.5-3.5$ & $9.3 \pm 1.9$ & $6.1-12$ & $0.46 \pm 0.04$ & $0.41-0.54$ & $0.61 \pm 1.13$ & $0.0-2.9$ & $1.2 \pm 0.30$ & $0.78-1.6$ & $18 \pm 9.1$ & $11-36$ \\
\hline
\end{tabular}




\begin{tabular}{|c|c|c|c|c|c|c|c|c|c|c|c|c|}
\hline \multirow[b]{3}{*}{$\begin{array}{l}\text { D. Sargus } \\
2014\end{array}$} & \multicolumn{2}{|c|}{$\mathbf{C u}\left(m g \cdot k g^{-1} d m\right)$} & \multicolumn{2}{|c|}{$\mathbf{Z n}\left(m g . k g^{-1} d m\right)$} & \multicolumn{2}{|c|}{ As $\left(m g . k g^{-1} d m\right)$} & \multicolumn{2}{|c|}{ Se $\left(m g . k g^{-1} d m\right)$} & \multicolumn{2}{|c|}{$\mathbf{P b}\left(m g \cdot k g^{-1} d m\right)$} & \multicolumn{2}{|c|}{ Total Hg $\left(m g . k g^{-1} d m\right)$} \\
\hline & Mean \pm sd & Mean \pm sd & Min - Max & Mean \pm sd & Mean \pm sd & Min - Max & Mean \pm sd & Mean \pm sd & Mean \pm sd & Min - Max & Mean \pm sd & $\begin{array}{l}\text { Min - } \\
\text { Max } \\
\end{array}$ \\
\hline & & & & & & & & & & & & \\
\hline $\operatorname{DLE}(\mathrm{n}=5)$ & $1.6 \pm 0.32$ & $1.2-2.0$ & $24 \pm 3.8$ & $20-29$ & $22 \pm 5.6$ & $17-29$ & $1.3 \pm 0.19$ & $0.98-1.5$ & $0.10 \pm 0.07$ & $0.00-0.17$ & $0.55 \pm 0.37$ & $0.13-1.1$ \\
\hline MAG $(n=5)$ & $2.3 \pm 0.40$ & $1.8-2.8$ & $31 \pm 1.9$ & $29-34$ & $25 \pm 5.4$ & $17-30$ & $1.3 \pm 0.15$ & $1.2-1.6$ & $0.05 \pm 0.04$ & $0.00-0.08$ & $0.47 \pm 0.36$ & $0.17-1.1$ \\
\hline $\operatorname{STM}(n=5)$ & $2.9 \pm 1.4$ & $1.6-5.1$ & $32 \pm 5.7$ & $24-40$ & $19 \pm 8.3$ & $8.6-31$ & $1.4 \pm 0.16$ & $1.2-1.6$ & $0.07 \pm 0.03$ & $0.05-0.11$ & $0.44 \pm 0.11$ & $0.34-0.59$ \\
\hline $\begin{array}{l}\quad \mathrm{TLN}(\mathrm{n}=5) \\
\text { D. vulgaris } \\
\text { 2014 }\end{array}$ & $2.2 \pm 0.21$ & $1.9-2.4$ & $28 \pm 2.5$ & $25-32$ & $16 \pm 6.1$ & $11-26$ & $1.4 \pm 0.17$ & $1.1-1.6$ & $0.20 \pm 0.09$ & $0.12-0.36$ & $0.40 \pm 0.05$ & $0.35-0.48$ \\
\hline DLE $(n=4)$ & $1.8 \pm 0.42$ & $1.5-2.4$ & $45 \pm 11$ & $35-61$ & $20 \pm 16$ & $9.4-44$ & $1.9 \pm 0.36$ & $1.3-2.2$ & $0.19 \pm 0.09$ & $0.11-0.30$ & $0.27 \pm 0.08$ & $0.19-0.39$ \\
\hline $\operatorname{MAG}(\mathrm{n}=5)$ & $2.2 \pm 0.24$ & $1.8-2.4$ & $39 \pm 12$ & 26- 57 & $17 \pm 6.8$ & $7.2-26$ & $1.8 \pm 0.11$ & $1.7-1.9$ & $0.15 \pm 0.07$ & $0.11-0.27$ & $0.12 \pm 0.03$ & $0.08-0.17$ \\
\hline STM $(n=4)$ & $2.9 \pm 1.0$ & $2.0-4.3$ & $31 \pm 24$ & $1.7-60$ & $11 \pm 7.7$ & $1.3-20$ & $1.7 \pm 0.17$ & $1.5-1.9$ & $0.12 \pm 0.04$ & $0.09-0.17$ & $0.23 \pm 0.02$ & $0.21-0.26$ \\
\hline $\begin{array}{l}\quad \mathrm{TLN}(\mathrm{n}=4) \\
\text { D. vulgaris } \\
\text { 2015 }\end{array}$ & $2.1 \pm 0.73$ & $1.6-3.2$ & $34 \pm 3.5$ & $30-38$ & $13 \pm 2.9$ & $9.6-16$ & $1.5 \pm 0.17$ & $1.4-1.7$ & $0.19 \pm 0.04$ & $0.13-0.22$ & $0.29 \pm 0.04$ & $0.24-0.33$ \\
\hline $\operatorname{DLE}(n=5)$ & $2.7 \pm 0.63$ & $1.8-3.3$ & $26 \pm 3.1$ & $21-29$ & $8.4 \pm 1.2$ & $6.8-9.8$ & $2.3 \pm 0.45$ & $1.9-3.0$ & $0.22 \pm 0.13$ & $0.12-0.44$ & $0.25 \pm 0.03$ & $0.21-0.28$ \\
\hline $\operatorname{MAG}(n=3)$ & $3.1 \pm 0.28$ & $2.8-3.3$ & $31 \pm 4.6$ & $26-35$ & $8.0 \pm 2.6$ & $5.3-11$ & $2.4 \pm 0.23$ & $2.2-2.6$ & $0.09 \pm 0.05$ & $0.05-0.14$ & $0.1 \pm 0.01$ & $0.09-0.11$ \\
\hline $\operatorname{STM}(\mathrm{n}=5)$ & $5.6 \pm 1.9$ & $4.3-8.9$ & $30 \pm 2.6$ & $26-33$ & $7.8 \pm 1.9$ & $6.2-11$ & $2.6 \pm 0.57$ & $1.9-3.4$ & $0.13 \pm 0.06$ & $0.09-0.24$ & $0.25 \pm 0.04$ & $0.21-0.31$ \\
\hline $\operatorname{TLN}(\mathrm{n}=6)$ & $2.6 \pm 0.54$ & $1.7-3.3$ & $27 \pm 2.8$ & $24-32$ & $8.4 \pm 1.0$ & $6.4-9.5$ & $1.6 \pm 0.17$ & $1.3-1.8$ & $0.23 \pm 0.11$ & $0.10-0.36$ & $0.29 \pm 0.02$ & $0.26-0.32$ \\
\hline
\end{tabular}




\section{Figures}

Figure 1: location of the 4 sites (O) sampled in the Bay of Toulon (Northwestern Mediterranean)

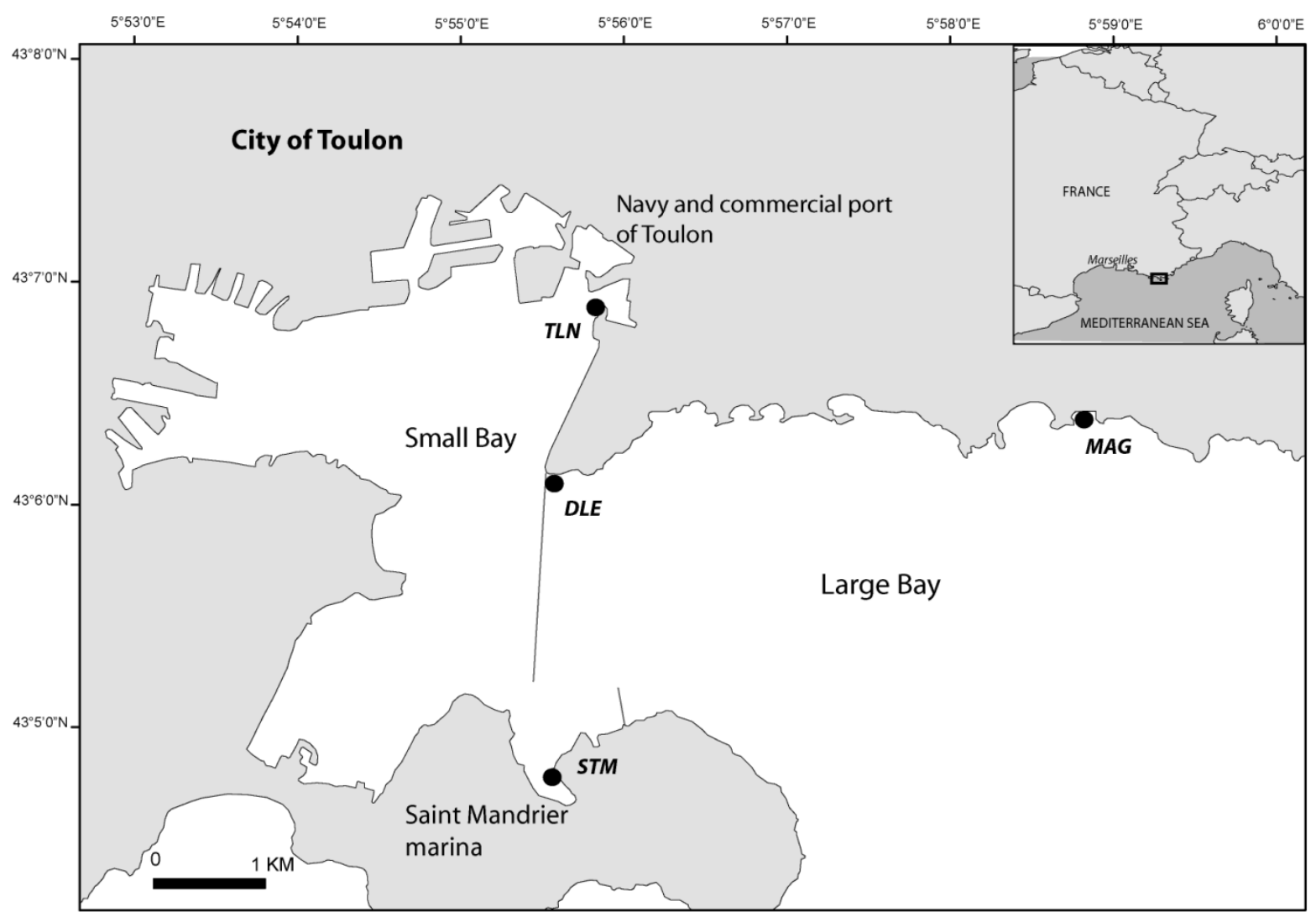


Figure 2: Comparisons of trace element contamination in the water column among the four sampling sites studied, inside (STM and TLN) and outside (DLE and MAG) ports in the Bay of Toulon. Letters indicate significant differences $(\mathrm{p}<0.05)$ between sites.

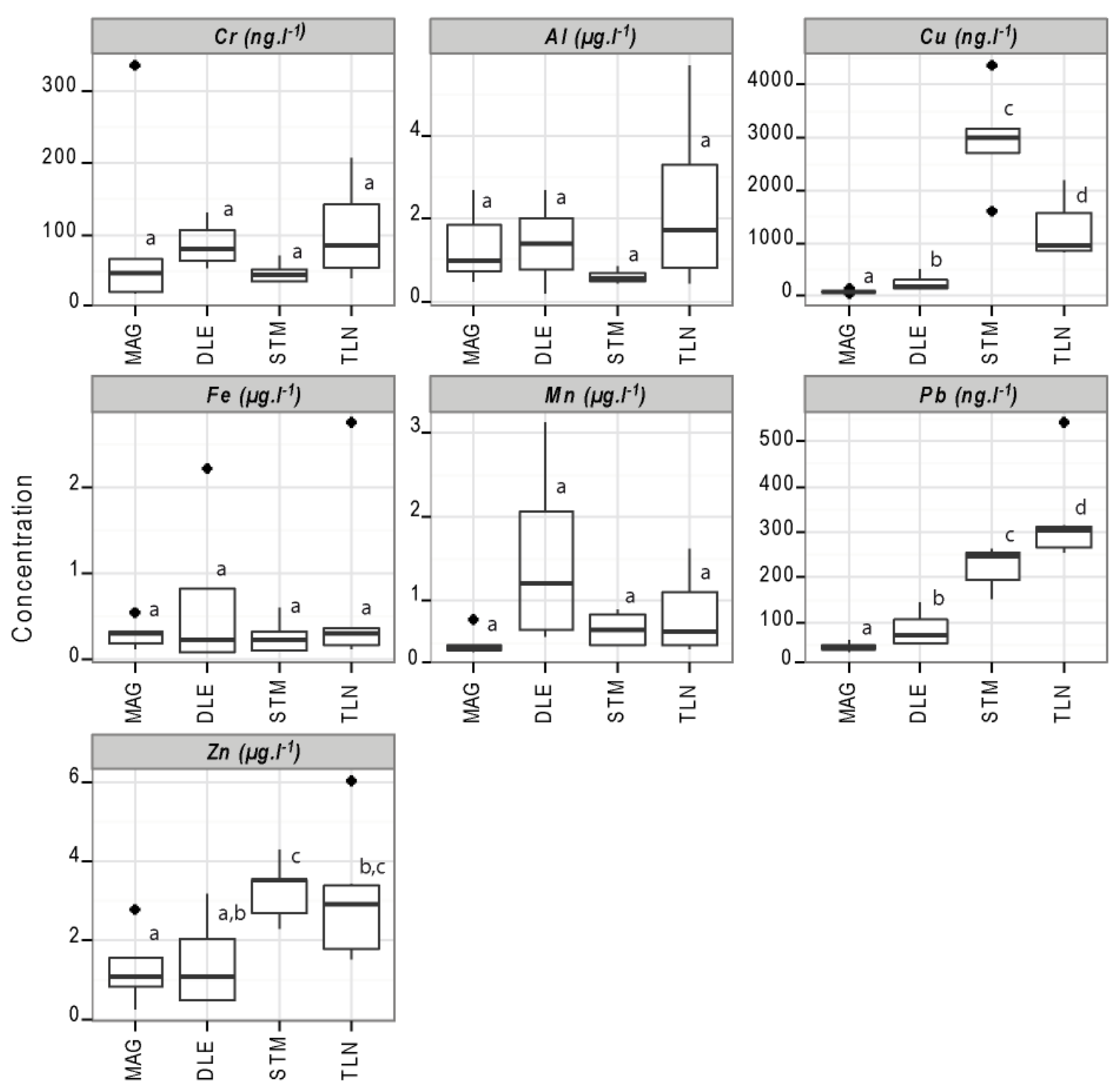


Figure 3: Comparisons of AGR and Fulton's $\mathrm{K}$ index in D. sargus and D. vulgaris juveniles. For each species and year, letters indicate significant differences $(\mathrm{p}<0.05)$ among the four sampling sites studied, inside (STM and TLN) and outside (DLE and MAG) ports in the Bay of Toulon. Statistical comparisons between species or years are not presented.

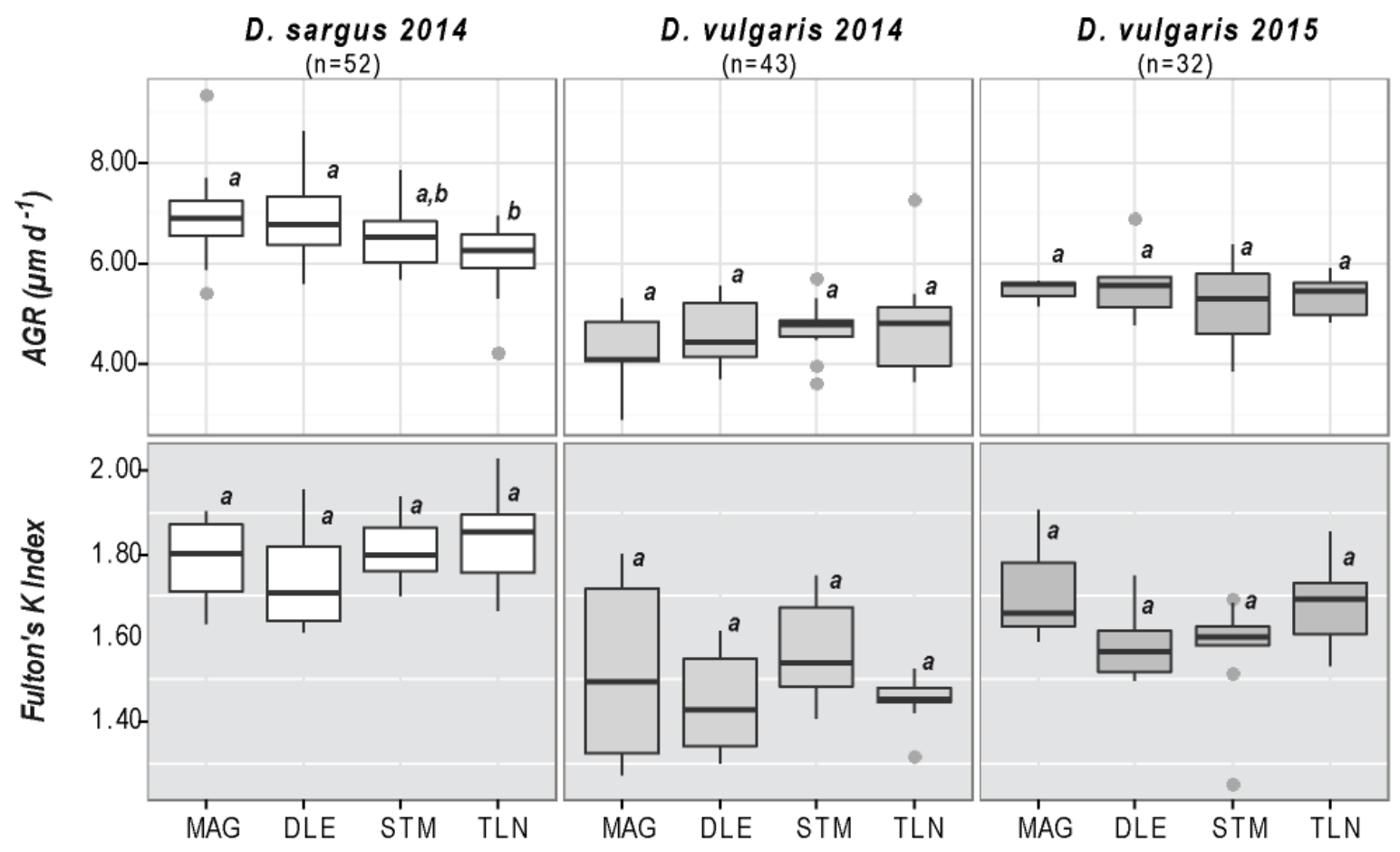


Figure 4: Variation of $\mathrm{Cu}, \mathrm{Mn}, \mathrm{Pb}$ and $\mathrm{V}$ concentrations in the muscle tissue of juvenile $D$. sargus and D. vulgaris. For each species and year, letters indicate significant differences $(\mathrm{p}<0.05)$ among the four sampling sites studied, inside (STM and TLN) and outside (DLE and MAG) ports in the Bay of Toulon . Statistical comparisons between species or years are not presented.

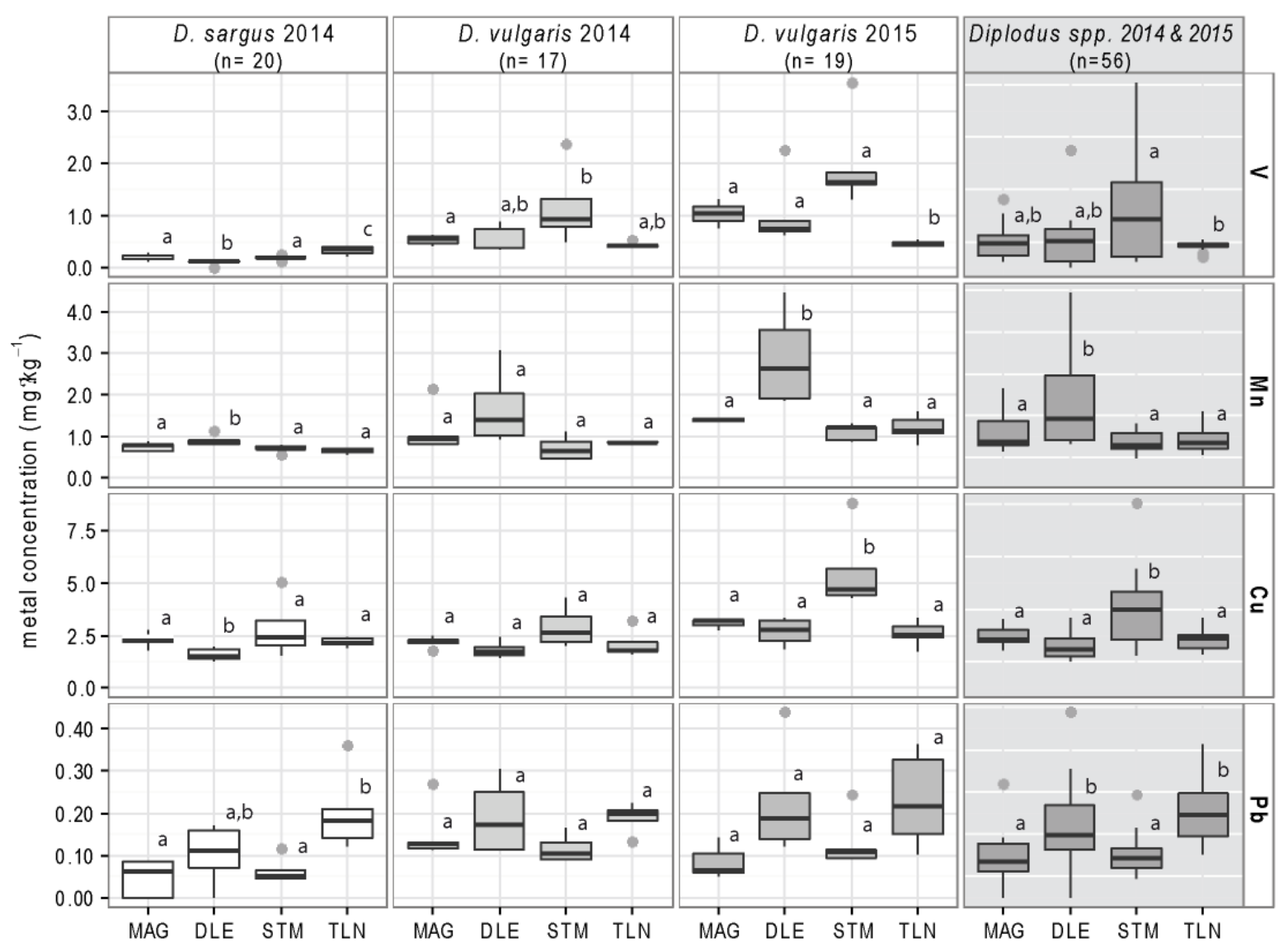


Supplementary material

Figure S1: Variation of $\mathrm{Al}, \mathrm{As}, \mathrm{Cr}, \mathrm{Fe}, \mathrm{Hg} \mathrm{Zn}, \mathrm{Se}$ and $\mathrm{Ti}$ concentrations in the muscle tissue of juvenile $D$. sargus and $D$. vulgaris. For each species and year, letters indicate significant differences (p $<0.05$ ) among the four sampling sites studied, inside (STM and TLN) and outside (DLE and MAG) ports in the Bay of Toulon. Statistical comparisons between species or years are not presented.

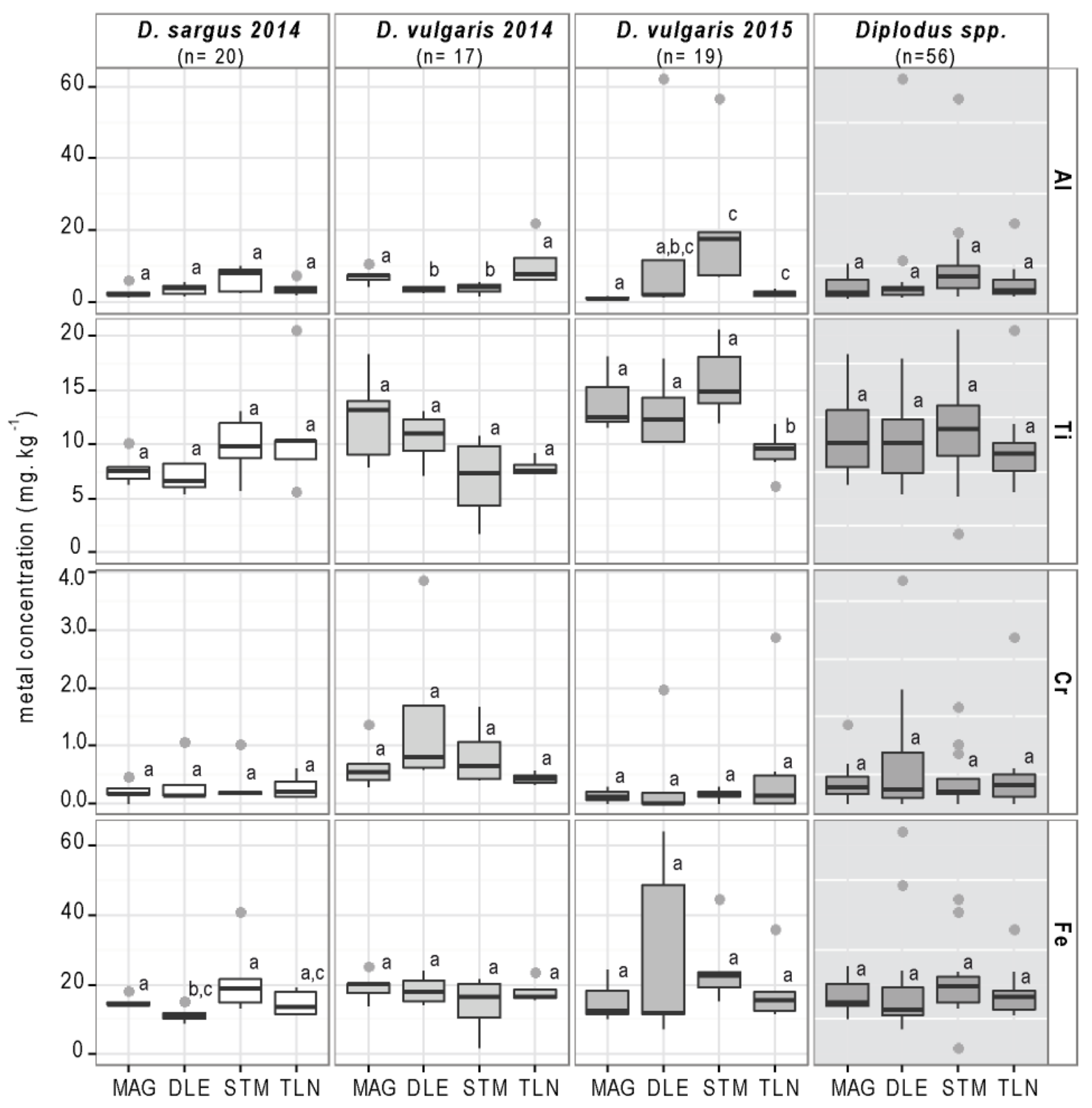




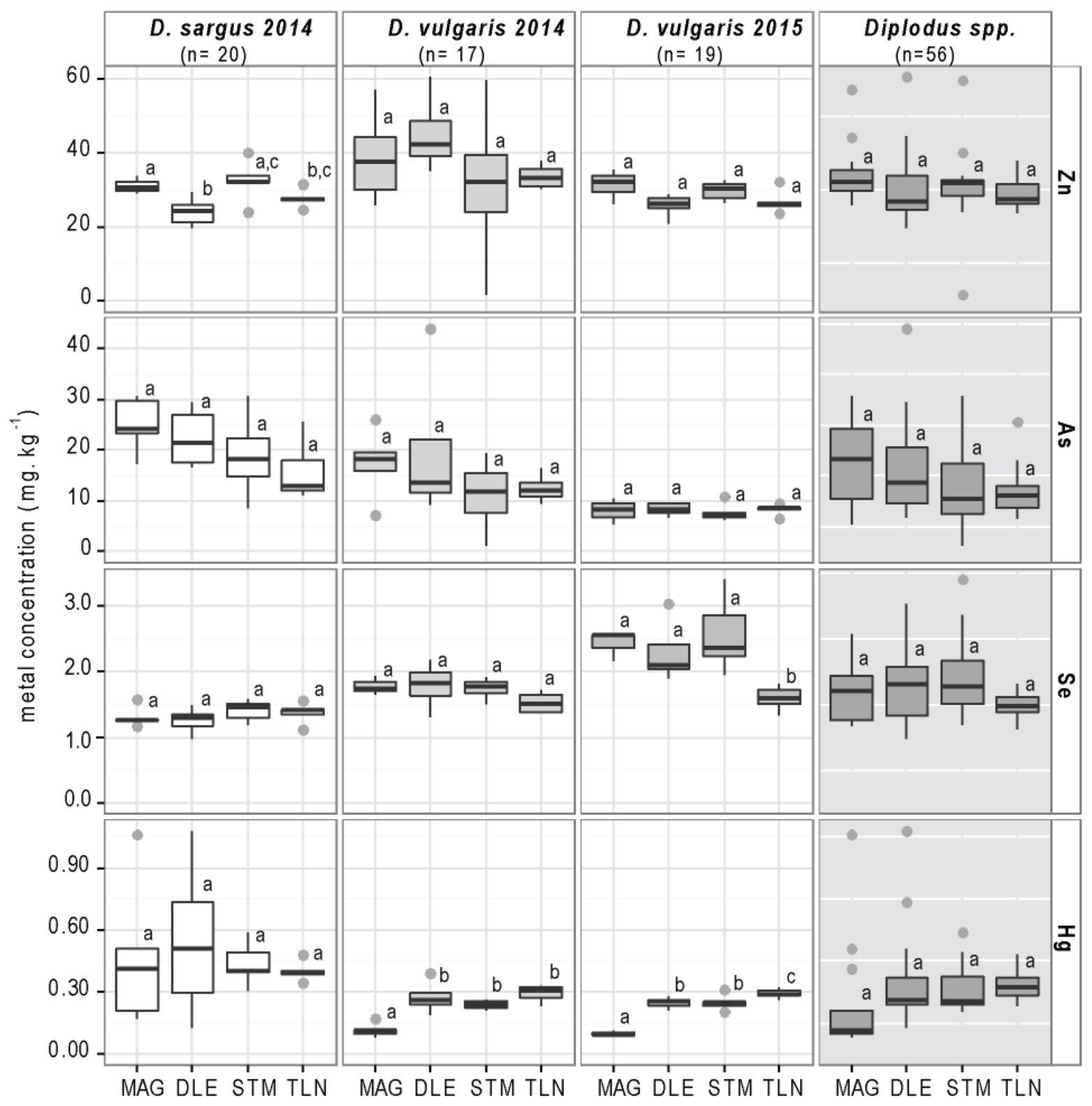

